\title{
Do Low Human Capital Coefficients Make Sense? A Puzzle and Some Answers
}

\author{
Ruth Judson \\ Federal Reserve Board \\ June 1995
}

In this paper, I develop a new measure of human capital stock that has two advantages over previous measures. First, it allows for the fact that the cost of education varies across time, countries, and levels. Second, the unit of measurement is dollars, which allows comparison of human capital stocks with other macroeconomic variables, including national income (GDP) and physical capital stocks. Using cross-country panel regression analysis, I find that human capital accumulation accounts for a relatively small (about ten percent) of per-capita GDP growth. I further find that, unlike physical capital, the stock of human capital as a share of GDP increases with GDP.

on the puzzle of why the human capital coefficient is often lower than theory would predict, and whether such estimates are believable. In order to do this, I develop a new measure of human capital stocks that has two advantages over previous measures. First, it allows for the fact that the cost of education varies across time, countries, and levels. Second, the unit of measurement is dollars, which allows comparison of human capital stocks with other macroeconomic variables, including national income (GDP) and physical capital stocks. Using cross-country panel regression analysis, I find that human capital accumulation accounts for a relatively small (about ten percent) of per-capita GDP growth. I further find that, unlike physical capital, the stock of human capital as a share of GDP increases with GDP. 


\section{Do Low Human Capital Coefficients Make Sense?}

\section{A Puzzle and Some Answers}

Individuals and governments invest vast quantities of resources in education, and there is substantial evidence that it is a worthwhile investment: individuals who are more educated earn higher wages, richer countries have higher levels of literacy and educational attainment, and the countries that experience rapid economic growth are often the ones that have invested heavily in education. Education, or the human capital it creates, is a key input in new macroeconomic models, including those of Lucas (1988), Romer (1990), Jovanovic, Lach, and Lavy (1992), and Azariadis and Drazen (1990).

In the past five years, new cross-country macroeconomic datasets have been assembled by Heston and Summers (1992), the World Bank, the International Monetary Fund, and others. These datasets include measurements of key macroeconomic variables for as many as 138 countries and 41 years. They allow economists to analyze economic growth and development with data from a wide sample of countries, circumstances, and stages of development.

Since education is supposed to be important, we might expect measures of education to enter significantly and with large coefficients in regressions that analyze growth. There are three basic types of growth regression that researchers estimate; only one yields any significant role for human capital. The first type of regression is a reduced form regression. In these regressions, average GDP growth rates are regressed on initial conditions and other level and change variables that are expected to influence growth. The second type of regression is based on the growth decomposition of the Cobb-Douglas production function. In these regressions, GDP growth is regressed on growth rates of factor inputs. Estimation of these two types of regressions has typically yielded implausibly low, 
statistically insignificant, or negative coefficients on human capital variables. The last type of regression is based on an extension of the Solow (1957) model's predictions about steady-state growth. It is this type of estimation that yields the one exception: a high, positive, and statistically significant coefficient for human capital. Mankiw, Romer, and Weil (1992) add human capital to the Cobb-Douglas production function used by Solow and find that estimation of the steady-state equation yields a coefficient around 0.3 for human capital, implying a share in production and an elasticity with respect to growth of nearly one third.

Table 1 displays the results of estimation of the human capital coefficient from various studies. The first column identifies the study; the second through fourth columns identify the estimation method, model, and measure of human capital (HK) used. The coefficient estimates are not directly comparable with each other because the human capital variable is not always a growth rate. Mankiw, Romer, and Weil (1992) use secondary school enrollment as a proxy for human capital accumulation; they claim that secondary enrollment is collinear with human capital accumulation, which is all they need in their model. 
World Development Report (1991) and Benhabib and Spiegel (1992) also use absolute changes in

Table 1: Summary of Cross-Country Regression Results

\begin{tabular}{||l|l|l|l|l|l||}
\hline \multicolumn{1}{|c|}{ Author } & \multicolumn{1}{|c|}{ Model } & \multicolumn{1}{|c|}{$\begin{array}{c}\text { Human Capital } \\
\text { (HK) } \\
\text { Variable }\end{array}$} & \multicolumn{1}{|c|}{ Technique } & \multicolumn{1}{|c||}{ Coefficient } & T \\
\hline \hline $\begin{array}{l}\text { Mankiw, } \\
\text { Romer \& } \\
\text { Weil 1992 }\end{array}$ & $\begin{array}{l}\text { Augmented Solow, } \\
\text { Steady state }\end{array}$ & $\begin{array}{l}\text { Secondary } \\
\text { enrollment }\end{array}$ & $\begin{array}{l}\text { Cross-section } \\
\text { OLS }\end{array}$ & 0.28 & 9.3 \\
\hline $\begin{array}{l}\text { Barro and } \\
\text { Lee 1992 }\end{array}$ & Reduced form & $\begin{array}{l}\text { Log of Barro- } \\
\text { Lee HK }\end{array}$ & $\begin{array}{l}\text { Cross-section } \\
\text { OLS }\end{array}$ & 0.057 & 3.0 \\
\hline $\begin{array}{l}\text { Barro and } \\
\text { Lee 1992 }\end{array}$ & Reduced form & $\begin{array}{l}\text { Log of Barro- } \\
\text { Lee HK }\end{array}$ & Pooled panel & 0.021 & 5.2 \\
\hline $\begin{array}{l}\text { Romer 1990 } \\
\text { Reduced form }\end{array}$ & $\begin{array}{l}\text { Literacy rate, } \\
\text { change }\end{array}$ & $\begin{array}{l}\text { Cross-section } \\
\text { instrumental } \\
\text { variables }\end{array}$ & 0.204 & 2.3 \\
\hline \hline WDR 1991 & $\begin{array}{l}\text { Augmented Solow, } \\
\text { production function }\end{array}$ & $\begin{array}{l}\text { WDR HK, } \\
\text { change }\end{array}$ & $\begin{array}{l}\text { Pooled panel, } \\
\text { annual data }\end{array}$ & $\begin{array}{l}\text { Ed<3 yrs: } 0.09 \\
\text { Ed>3 yrs: } 0.04\end{array}$ & $\begin{array}{l}2.6 \\
2.0\end{array}$ \\
\hline $\begin{array}{l}\text { Benhabib- } \\
\text { Spiegel, } \\
1992\end{array}$ & $\begin{array}{l}\text { Augmented Solow, } \\
\text { production function }\end{array}$ & $\begin{array}{l}\text { Kyriacou HK, } \\
\text { change }\end{array}$ & Cross-section & -0.021 & 1.4 \\
\hline $\begin{array}{l}\text { Lau et al., } \\
1991\end{array}$ & $\begin{array}{l}\text { Augmented Solow, } \\
\text { production function }\end{array}$ & $\begin{array}{l}\text { WDR HK, log } \\
\text { difference }\end{array}$ & $\begin{array}{l}\text { Pooled panel, } \\
\text { annual }\end{array}$ & 0.016 & 1.6 \\
\hline $\begin{array}{l}\text { Judson 1993 } \\
\text { pugmented Solow, } \\
\text { production function }\end{array}$ & $\begin{array}{l}\text { Judson HK, } \\
\text { growth rate }\end{array}$ & Panel GLS & 0.098 & 4.3 \\
\hline \hline
\end{tabular}

average years of education of the labor force rather than percentage changes. Romer (1990) considers literacy a proxy for human capital stock and uses the change in the literacy rate. Barro and Lee (1992) use the log level of their measure of average education of the labor force. Finally, Lau, Jamison and Louat (1991) use the log difference of the World Development Report's (1991) measure of average years of education of the labor force, which is approximately equal to the percentage growth rate. This is the only measure that is comparable to the growth rate that I use; I obtain a 
coefficient of 0.098 , more than five times that obtained by Lau, Jamison, and Louat (1991) but only a third as large as that obtained by Mankiw, Romer, and Weil (1992).

Three questions emerge: first, which estimate of the parameter for human capital in a CobbDouglas production function is correct econometrically? Second, does the coefficient make sense in the context of both micro evidence about returns to education and the Cobb-Douglas production function? Third, what are the implications for human capital investment and our understanding of economic growth if the lower coefficient is right?

In this chapter, I first outline the extended Solow model proposed by Mankiw, Romer, and Weil (1992). I use the same production function as they do to link the relative returns to human and physical capital, the relative stocks of human and physical capital in the economy, and their relative coefficients in the regression equation derived from the same model. I then review the evidence on returns to physical and human capital investment across countries and time. Next, I develop a new human capital series that measures the stock of human capital in value rather than in person-years. This measure of human capital eases comparison of the stock of human capital with that of physical capital over time and across countries. Finally, I review and test the specifications of the extended Solow model that have produced the macroeconomic parameter estimates.

Using the new measure of human capital stock and the production function specification, I find a robustly positive human capital coefficient that is two to three times larger than comparable figures found in earlier studies but still well below the estimate of 0.3 of Mankiw, Romer, and Weil (1992). Further, I find that a low value for the share of human capital in the growth decomposition is plausible both econometrically and in the context of the Cobb-Douglas form of the production function, and that the relationship between human and physical capital stocks and returns and their regression coefficients predicted by the production function in Mankiw, Romer, and Weil's (1992) 
extended Solow model holds approximately. Human capital thus belongs in the production function and is still a high-return input, but its role is not as large as that of physical capital.

However, I also find that the path of human capital accumulation as wealth increases is distinctly different from that of physical capital: the human capital to output ratio is increasing in output but the physical capital to output ratio shows no trend. This is not explained or predicted by any of the new growth models that I am aware of. However, the Solow model does not predict these patterns either. Measuring human capital as I do also allows me to examine some of the predictions about human capital accumulation and growth that are implied by newer models of growth. I find that none of the predictions of the new growth theory about the relationships between levels and growth rates of income and human capital hold. In sum, while the Cobb-Douglas form of production in the augmented Solow model provides a reasonable description of growth, it must be considered a starting point rather than an endpoint in our thinking about the role of human capital in growth and development.

In Section 1 I derive the relationship between human and physical capital levels, returns, and regression coefficients that is implied by the extended Solow growth model with a Cobb-Douglas production function. In Sections 2, 3, and 4 I discuss the data available for the three ratios that form this relation. First, in Section 2, I review the evidence on returns to human and physical capital. Second, in Section 3, I develop a new human capital series that measures the value of education embodied in the labor force at a particular time. Third, in Section 4 I estimate the parameters of the Cobb-Douglas production function with a cross-country panel regression. I also calculate productivity residuals and review other regression estimates of the production function parameters. In Section 5, I conclude and discuss the implications for human capital accumulation. In Section 6 I return to the properties of the data and compare them to the predictions of several new growth models. 


\section{The Extended Solow Model and the Human Capital Coefficient}

\section{A. The Solow Growth Decomposition}

In the original Solow (1957) growth decomposition, technical progress is neutral so that production takes the form:

$$
Y=A F(K, L)
$$

If the production function is Cobb-Douglas in physical capital and labor, then

$$
Y=A K^{\alpha} L^{1-\alpha}
$$

Taking time derivatives of the production function and dividing through by $\mathrm{Y}$ yields:

$$
\frac{\dot{Y}}{Y}=\frac{\dot{A}}{A}+\alpha \frac{\dot{K}}{K}+(1-\alpha) \frac{\dot{L}}{L}
$$

In per worker growth rate terms we have:

$$
\frac{\dot{y}}{y}=\frac{\dot{A}}{A}+\alpha \frac{\dot{k}}{k}
$$

In order to measure the productivity residual, Solow calculated the input share $\alpha$ for physical capital for each year. He assumed constant returns to scale and complete classification of inputs as either physical capital or labor so that the shares would sum to one. He then calculated productivity residuals using this equation and data on output per man-hour and physical capital per man-hour. Solow estimated a separate physical capital share variable for each year. He found that physical capital's share in income varied from a low of 0.312 to a high of 0.397 .

New cross-country datasets permit similar analysis across a large sample of countries. However, the data available in these datasets are not nearly as rich as those available for the U.S. 
In particular, factor shares are not available, but growth rates of inputs are. Dropping the constantreturns-to scale assumption, imposing constancy of factor shares, and adding an error term yields the regression form of the Solow growth decomposition:

$$
\frac{\dot{Y}}{Y}=\beta_{0}+\beta_{K} \frac{\dot{K}}{K}+\beta_{L} \frac{\dot{L}}{L}+\epsilon
$$

Cross-country regressions with panel and cross-section data yield coefficient estimates close to those calculated by Solow; these will be discussed in Section IV.

\section{B. The Extended Solow Model with Human Capital}

Mankiw, Romer and Weil (1992) propose an extension of the Solow model in which production is Cobb-Douglas in three inputs: labor $(\mathrm{L})$, physical capital $(\mathrm{K})$, and human capital $(\mathrm{H}):^{1}$

$$
Y=A_{t} K^{\alpha} H^{\beta} L^{\gamma}
$$

As with the original Solow model, taking time derivatives, imposing constant returns to scale, and adding an error term yields an equation for the growth of output in terms of growth of labor, physical capital, and human capital:

$$
\frac{\dot{Y}}{Y}=\frac{\dot{A}}{A}+\alpha \frac{\dot{K}}{K}+\beta \frac{\dot{H}}{H}+(1-\alpha-\beta) \frac{\dot{L}}{L}+\epsilon
$$

Assuming that inputs are paid their marginal products, this model allows us to write an equation relating rates of return, levels, and coefficients for pairs of inputs. First, note that if returns

\footnotetext{
${ }^{1}$ Constant returns are imposed by setting $\gamma$ equal to $1-\alpha-\beta$.
} 
are equal to marginal products, then

$$
\begin{aligned}
& r_{K}=\frac{\partial Y}{\partial K}=A \beta K^{\alpha-1} H^{\beta} L^{1-\alpha-\beta} \\
& r_{H}=\frac{\partial Y}{\partial H}=A \alpha K^{\alpha} H^{\beta-1} L^{1-\alpha-\beta}
\end{aligned}
$$

Taking the ratio of marginal products gives

$$
\frac{r_{K}}{r_{H}}=\frac{\alpha}{\beta} \frac{H}{K}
$$

which is the relationship I will examine. I calculate the three ratios in this equation and show that, on average, they satisfy this equation. The ratio of returns is discussed in Section 2, the ratio of the stock of human capital to physical capital is calculated in Section 3, and the ratio of the coefficients of the production function is estimated in Section 4.

\section{Returns to Human and Physical Capital}

\section{A. Returns to Human Capital in the Form of Education}

Proponents of investment in education argue that education is a good investment because it yields a high return, usually much higher than that of physical capital. Indeed, the rates of return calculated and compiled by Psacharopoulos $(1993,1985)$ are impressively high. Table 2 displays rates of return to education calculated and assembled by Psacharopoulos (1993). For each region, the average includes the most recent observation for each country for which data are available. Private rates of return are higher than social rates of return because private returns exclude the public 
Table 2: Rates of Return to Education, Various Levels, By Region

\begin{tabular}{||l|c|c|c|c|c|c||}
\hline \multirow{2}{*}{ Region } & \multicolumn{3}{|c|}{ Social } & \multicolumn{3}{c||}{ Private } \\
\cline { 2 - 8 } & Primary & $\begin{array}{l}\text { Secon- } \\
\text { dary }\end{array}$ & Higher & Primary & $\begin{array}{l}\text { Secon- } \\
\text { dary }\end{array}$ & Higher \\
\hline Sub-Saharan Africa & 24.3 & 18.2 & 11.2 & 41.3 & 26.6 & 27.8 \\
\hline Asia (non-OECD) & 19.9 & 13.3 & 11.7 & 39.0 & 18.9 & 19.9 \\
\hline Europe/M.East/N.Africa & 15.5 & 11.2 & 10.6 & 17.4 & 15.9 & 21.7 \\
\hline Latin America/Caribbean & 17.9 & 12.8 & 12.3 & 26.2 & 16.8 & 19.7 \\
\hline OECD & 14.4 & 10.2 & 8.7 & 21.7 & 12.4 & 12.3 \\
\hline World & 18.4 & 13.1 & 10.9 & 29.1 & 18.1 & 20.3 \\
\hline Source: Psacharopoulos (1993), p. 7. & & & & \\
\hline
\end{tabular}

component of the costs of education. ${ }^{2} \quad$ As with physical capital returns, I construct five-year averages of the return to education data, which are available quite sporadically. Figure 1, Figure 2, and Figure 3 display private rates of return to primary, secondary, and higher education against GDP. Rates of return to all levels of education fall as GDP rises.

These rates of return were calculated either by the earnings function method due to Mincer (1974) or by what Psacharopoulos (1993) calls the full method. In the full method, the return is the discount rate that equates the costs of education, including foregone wages and other costs, and the benefits of education in the form of increased wages. Social rates of return include in the costs of education both foregone income and the full cost of education, including that borne by the

${ }^{2}$ All returns to education are assumed to be captured by the individual's wage; social benefits to adding to the stock of educated people are not measured in the calculation of either private or social rates of return. 
government; private returns include only foregone income and private educational expenses in the cost of education. Since the private costs of education are often lower than the social costs, private rates of return to education are usually higher than social rates of return.

The full method is a compromise between the earnings function method due to Mincer (1974), which requires less data but is less flexible, and the net present value method, which is better but requires comprehensive earnings and education data on many individuals. The full method has two prominent drawbacks. First, it is very difficult to measure the ability of the students, which is clearly an important input (See, e.g., Griliches (1977)). Second, it is difficult to calculate foregone earnings for children in general and for the very uneducated in countries where primary education is close to universal. In fact, it is nearly impossible to obtain the relevant wage data for children from crosscountry sources because countries are unwilling to admit that they have child labor, which they would implicitly do by providing such data. These problems are common, however, to many measures of returns to education. In the full method, researchers can adjust for the fact that foregone income for children might be less than that for adults by assuming that children only forego income for part of their time in school. However, Psacharopoulos (1993) notes that relatively few studies do this.

The full method is the method preferred by Psacharopoulos (1993). However, for some countries, only rate of return data calculated by the earnings function method are available; in this case, Psacharopoulos reports them. In the earnings function method, the log of wages is regressed on a constant, years of schooling, years of experience, years of experience squared, and other relevant variables. In such a regression, the private rate of return to a year of education comes from the coefficient on years of education. This method has the same drawbacks as the full method; in addition, as Psacharopoulos and Layard (1979) and Psacharopoulos and Ng (1992) have pointed out, it requires the assumption that earnings are the same at all times for a given level of education. 
Finally, both methods of estimating rates of return to education could be modified to allow for different rates of return to different types of education or different specializations, but data at this level of disaggregation are not available across many countries.

\section{B. Returns to Physical Capital}

Data on returns to physical capital that are comparable across a broad sample of countries are scarce, but they do exist. Some data are available on rates of return to public investment projects funded by the World Bank, but these data are confidential, spotty, and refer only to particular projects. In addition, the World Bank is not a typical investor. An alternative source of data is the rates of return for United States direct investment abroad, which are compiled by the Bureau of Economic Analysis. ${ }^{3}$ Although these data also focus on a small subsample of investment in each country, the measurements are consistent with each other and offer a means of comparing returns to physical capital across a broad sample of countries and time periods. In addition, they represent the returns to physical capital that can be obtained by private investors who have many investment options. I calculate returns to physical capital from the BEA data. For a given country and time period, returns are calculated as earnings divided by total investment outstanding. The BEA data are provided on an annual basis. In order to make them comparable to the rest of my data, I construct five-year averages of the returns.

${ }^{3}$ I am grateful to Elaine Buckberg for providing these data. 
Table 3: GDP Quintile, Region, and Time Averages of Returns to Capital and Human Capital

\begin{tabular}{|c|c|c|c|c|c|}
\hline Quintile & GDPC & KRET & PPRET & SPRET & HPRET \\
\hline 1 & 593 & 13.3 & 25.4 & 18.6 & 24.1 \\
\hline 2 & 1189 & 11.4 & 30.9 & 20.8 & 25.5 \\
\hline 3 & 2149 & 12.6 & 32.9 & 20.1 & 17.8 \\
\hline 4 & 4179 & 12.9 & 19.7 & 14.1 & 18.5 \\
\hline 5 & 9831 & 12.8 & 21.6 & 12.3 & 12.8 \\
\hline \multicolumn{6}{|c|}{ II.Quintile averages sorted by KRET, returns to physical capital. } \\
\hline Quintile & GDPC & KRET & PPRET & SPRET & HPRET \\
\hline 1 & 5925 & 5.5 & 20.2 & 12.7 & 15.1 \\
\hline 2 & 6447 & 9.3 & 25.2 & 17.4 & 17.4 \\
\hline 3 & 6660 & 12.4 & 29.4 & 12.2 & 11.9 \\
\hline 4 & 7049 & 15.5 & 12.5 & 10.9 & 15.8 \\
\hline 5 & 7070 & 22.3 & . & 18.5 & 25.2 \\
\hline \multicolumn{6}{|c|}{ III. Sorting by region } \\
\hline Region & GDPC & KRET & PPRET & SPRET & HPRET \\
\hline OECD & 8615 & 12.2 & 20.5 & 12.3 & 12.3 \\
\hline LACAR & 3529 & 11.6 & 23.8 & 15.6 & 20.0 \\
\hline MENA & 4198 & 19.5 & 12.7 & 17.8 & 21.8 \\
\hline ASIA & 2438 & 15.9 & 26.8 & 15.8 & 16.7 \\
\hline AFRICA & 1287 & 14.0 & 36.1 & 25.7 & 25.6 \\
\hline \multicolumn{6}{|c|}{ IV. Sorting by period } \\
\hline Period & GDPC & KRET & PPRET & SPRET & HPRET \\
\hline $61-65$ & 2436 & 10.7 & 21.2 & 15.2 & 13.5 \\
\hline $66-70$ & 2858 & 9.3 & 26.9 & 17.5 & 17.0 \\
\hline $71-75$ & 3468 & 11.5 & 25.2 & 13.4 & 17.6 \\
\hline $76-80$ & 3948 & 14.5 & 19.7 & 14.4 & 17.8 \\
\hline $81-85$ & 4151 & 13.0 & 44.1 & 24.3 & 25.2 \\
\hline $86-90$ & 4642 & 16.7 & 23.6 & 16.2 & 17.4 \\
\hline \multicolumn{6}{|c|}{$\begin{array}{l}\text { GDPC: Per-capita GDP, in } 1985 \text { PPP dollars from Heston-Summers 1992. KRET: } \\
\text { Rate of return to capital on U.S. Foreign Direct Investment, from BEA. PPRET, } \\
\text { SPRET, HPRET: Private return to primary, secondary, and higher education, from } \\
\text { Psacharopoulos (1993). }\end{array}$} \\
\hline
\end{tabular}


Table 3 provides descriptive statistics about returns to physical capital. In the first panel, the data are grouped into quintiles according to per-capita GDP. Thus, the first row displays group averages for the poorest twenty percent of the sample and the fifth row displays group averages for the richest quintile of the sample. We see that rates of return to physical capital do not vary systematically with GDP. However, returns to human capital decline as GDP increases. In the second panel, with quintile averages sorted by returns to physical capital (KRET), we see that per- 
capita GDP increases moderately with returns to physical capital but the other variables do not move with KRET in a systematic way. In the third and fourth panels, averages over regions and time periods, the same general patterns and correlations are discernible: GDP increases over time and is negatively correlated with returns to human capital; returns to physical capital increase weakly over time.

\section{Stocks of Physical Capital}

I use a physical capital stock dataset that was originally created for the 1991 World Development Report and subsequently updated by Nehru (1992). This series measures total capital stock using the perpetual inventory method and an initial capital stock value of zero. The measurements are in 1987 national currency units. In order to compare physical capital stock to GDP and human capital stocks, I use the IMF's real GDP figures. Since the IMF reports real GDP in 1985 units, I inflate the GDP series using either the IMF's GDP deflator where available and the consumer price index from the IMF otherwise.

Figure 4 to Figure 7 illustrate the relationships between returns to physical capital and the capital-labor ratio, capital per head, the ratio of human capital to physical capital, and GDP. There is little pattern to returns to physical capital: they are weakly positively correlated with the capitaloutput ratio and capital per capita; they are not correlated with GDP. Returns to physical capital are weakly negatively correlated with the ratio of human to physical capital. On average, rates of return to physical capital are lower than those for human capital. Across available observations, the mean ratio of physical capital returns to private human capital returns is 0.52 for primary education, 0.65 for secondary education, 0.68 for higher education, and 0.47 overall. 


\section{A New Human Capital Series}

I develop a new human capital series that estimates the value, in 1985 PPP dollars, of a country's human capital stock. Such a series has two advantages over existing measures and proxies for human capital stock. Many studies do not use direct measures of human capital; rather, they use proxies such as literacy (e.g., Benhabib and Spiegel (1993), Romer (1990)) or enrollment rates (e.g., Mankiw, Romer, and Weil (1992)). The proxies give an idea of how much human capital a country has, but any power they have depends on the assumption that the proxy is collinear with the country's whole human capital stock. More recent studies use series that measure human capital stock as average years of education of the labor force, as by World Development Report (1991) and Barro and Lee (1992). These series do not account for the fact that the relative cost of a year of primary education compared to that of higher education is not one and is not constant across countries. Nor do they account for the fact that the resources devoted to a year of primary, secondary, or higher education vary considerably across countries and time. In addition, person-years of education are difficult to compare to capital stocks, GDP, or other macroeconomic variables. This series corrects both problems.

My human capital series builds on those of Barro and Lee (1992) and Nehru et al. (1993), which measure the average educational attainment of the labor force in years of education. My innovation is to calculate the cost of education and to then weight primary, secondary, and higher education stocks according to their costs. This improvement is analogous to measuring physical capital by the cost of types of buildings and machines rather than just the number of them. It allows comparison of human capital stocks with physical capital stocks and GDP. In addition, growth rates of my series incorporate the changes as countries shift from expanding primary education, which is relatively inexpensive, into secondary and higher education, which tends to be more expensive. 
After discussing the construction of the series and presenting some descriptive statistics, I demonstrate that human capital accumulation behaves rather differently from that of physical capital. Finally, I use the series to form the ratio of physical to human capital, which gives the second ratio in Equation (9).

\section{A. Overview}

My human capital series combines data from three sources. I begin with Barro and Lee (1992) and Nehru et al. (1993) data on the average educational attainment of the labor force by level. Second, I use UNESCO data on school enrollments by level and education spending by level to obtain weights for the education stock at each level. I calculate per-pupil spending at each level of education for each country in each of the six five-year periods between 1960 and 1990. I use these spending figures to weight primary, secondary, and higher educational attainment as given by Barro and Lee (1992) and Nehru et al. (1993). This gives me a value for a country's total educational stock in nominal national currency units. Third, I convert these figures to 1985 prices using the UNESCO series on educational spending as a share of GDP and Heston-Summers GDP data. I use five-year intervals because most of the underlying data series are only available at five-year intervals anyway. Where more than one observation is available for a particular period, I use the average over available observations.

\section{B. Sources of Data}

I base my calculations on estimates of the average educational attainment of the labor force developed by Barro and Lee (1992) and Nehru et al. (1993). Both series consist of measurements of average primary, secondary, higher, and total educational attainment for a panel of about 80 
countries and the six five-year periods between 1960 and 1990. The two series differ in coverage, but are closely correlated $(\rho=0.75)$. They arrive at their estimates rather differently, however. Barro and Lee (1992) use census data as their starting point and augment it with other information about school enrollment and completion. Nehru et al. (1993), in a refinement of Jamison, Lau, and Louat (1991), use enrollment data as a base. Both methods require substantial simplifying assumptions and extrapolation. Barro and Lee measure the educational attainment of the labor force aged 25-64; Nehru et al. (1993) include all members of the labor force aged 15-64. Thus, Nehru et al.'s (1993) figures are more likely to capture more recent expansion of education in less developed countries. In addition, Nehru et al.'s (1993) dataset provides more observations. Thus, I use Nehru et al.'s (1993) series for the results reported here. However, the results do not change much when Barro and Lee's (1992) series is used.

To estimate the relative value of a year of education at each level, I use data from UNESCO and Heston-Summers (1992). UNESCO reports data on total, current, and capital spending on education by level in national currency units; it also reports total current spending as a share of GDP. I use current spending as the measure of spending for three reasons. First, it is available for a much larger sample of countries and periods than are capital and total spending. Second, it is a smoother measure of educational inputs. Third, it measures the most important educational inputs at least as accurately as total spending. ${ }^{4}$ UNESCO reports enrollment by sex, age, and level. I use total enrollment at each level for both sexes. I choose this measure for two reasons. First, it is more widely available. Second, it does not make sense to ignore older students since they too are accumulating human capital and using educational inputs.

${ }^{4}$ Research on educational inputs in the United States indicates that current expenditures are much more highly correlated with school quality than capital or total expenditures. See, e.g. Schmidt (1993). 
The key series provided by UNESCO is current spending as a share of GDP. This ratio allows us to link spending, which is measured in nominal units, with real GDP. For real GDP, I use real GDP in 1985 purchasing power parity (PPP) dollars from Heston and Summers (1992)

The formulas and notation I use are:

$\mathrm{y}_{\mathrm{it}}=$ Per-capita GDP, in local currency, as reported by the IMF.

$\mathrm{y}_{\text {sit }}=$ Summers-Heston per-capita GDP, in 1985 PPP dollars

$\mathrm{E}_{\mathrm{ijt}}=$ Spending on level $j$ education in local currency

$\mathrm{E}_{\mathrm{it}}=$ Total spending on education, in local currency

$\mathrm{e}_{\mathrm{it}}=$ Average spending on education per pupil, local currency, all levels

$\mathrm{e}_{\mathrm{ijt}}=\quad$ Average spending per pupil at level $j$

$\mathrm{s}_{\mathrm{ijt}}=\quad$ Spending per pupil as a percentage of per-capita GDP $=\mathrm{e}_{\mathrm{ijt}} / \mathrm{y}_{\mathrm{it}}$

$\mathrm{S}_{\mathrm{it}}=\quad$ Spending on education as a percentage of total GDP $=\mathrm{E}_{\mathrm{it}} / \mathrm{Y}_{\mathrm{it}}$

$\mathrm{P}_{\mathrm{it}}=$ Population

$\mathrm{L}_{\mathrm{it}}=$ Labor force

$\mathrm{a}_{\mathrm{ijt}}=$ Average educational attainment of the labor force.

Indices: $i$ indexes the country, $t$ indexes time, and $j$ indexes the level of education.

UNESCO provides the ratio $\mathrm{S}_{\mathrm{it}}=\mathrm{E}_{\mathrm{it}} / \mathrm{Y}_{\mathrm{it}}$. This ratio is an average across all levels of education. It is appealing to use because the units are the same, namely nominal local currency units. The ratio $\mathrm{s}_{\mathrm{ijj}}$, education spending per pupil at the $j^{\prime}$ th level as a percentage of per-capita GDP, can be obtained as follows:

$$
S_{i j t}=\frac{e_{i j t}}{y_{i t}}=\frac{e_{i j t}}{\left(S_{i t}^{-1}\left(\sum_{j} E_{i j t} / P_{i t}\right)\right)}=\left(\frac{P_{i t}}{\sum_{j} E_{i j t}}\right) S_{i t} e_{i j t}
$$


To translate this cost into dollars, I multiply the ratio of spending per pupil to per-capita GDP times Heston-Summers real per-capita GDP in 1985 prices:

$$
d_{i j t}=e y_{i j t} y_{s i t}
$$

I then use the $\mathrm{d}_{\mathrm{ijt}}$ as weights for the measures of human capital present in an economy. My measure of average human capital per worker is:

$$
h_{i t}=\sum_{j} d_{i j t} a_{i j t}
$$

The measure of capital in the whole economy is then

$$
H_{i t}=h_{i t} L_{i t}
$$

\section{Assumptions and Data Problems}

The key assumption I use is that government expenditure on education is a good measure of its quality, or at least of the value of the education provided. Card and Krueger (1992) have found that measures of the quality of education are correlated with future earnings. The quality measures they use are term length, pupil-teacher ratio, and teacher pay, all of which can only be improved by spending more. Ideally, we would also have some measure of the quality of the students being trained; I have considered this topic in Chapter Two and concluded that growth in countries that allocate their educational resources poorly may not be correlated with human capital accumulation. In addition, I have to interpolate some sporadically-measured variables. In all cases, I use geometric interpolation, which forces a constant growth rate rather than constant level change between missing observations. I use the following order of operations:

1. Interpolate input series, including those for enrollments, spending, and education spending as a share of GDP. 
2. Create human capital series.

3. Interpolate results.

4. Create annual growth rates of all series.

5. Create five-year average growth rates of all series.

There are two major shortcomings of this series. First, it measures the price of producing human capital at a given time, which is not exactly the same as its replacement value. Since human capital in the form of education lasts for a very long time, the current production cost might not be an accurate indicator of the value of older human capital, especially if a country upgrades the quality of its schools over time. To make the series analogous to capital series, the weights would vary according to the vintage of the human capital and, perhaps, the amount of labor force experience individuals have. This would be possible only with very long series in which the vintage of the human capital is known. Second, we might want to include the cost of foregone labor income as a cost of human capital. But this is nearly impossible with current data sources, especially for childhood, when most students are in school. In the absence of accurate data on foregone income, I could simply scale all human capital stocks by some constant to account for the foregone income component of human capital. I do not do this for two reasons. First, it would not change the regression results at all since scaling the stocks does not affect growth rates. Accurate accounting for foregone income would probably change growth rates, but is impossible. Second, for public policy purposes, the direct costs of education, which are usually borne by the state, are much more of an issue than foregone income, which is usually borne by individuals.

\section{The Dataset: Descriptive Statistics}

Table 4 provides an overview of the data, including growth rates for human capital (ZJNHK), 
physical capital-output ratios (KY), human capital-output ratios (HY), and physical capital to human capital ratios $(\mathrm{KH})$. The striking result is the high ratios of physical to human capital stock. For lessdeveloped countries, the ratio can be higher than 20; for more-developed countries, the ratio is still around 2. The physical capital to human capital ratios decline over time and with per capita GDP. However, physical capital-output ratios are fairly stable across time, GDP, and continents. 
Table 4: Descriptive Statistics for Levels and Growth Rates of New Human Capital Series

\begin{tabular}{|c|c|c|c|c|c|c|}
\hline \multicolumn{7}{|c|}{ Sorting by per-capita GDP } \\
\hline Q & ZGDPC & ZJNHK & KH & KY & $\mathrm{HY}$ & GDPC \\
\hline 1 & 0.80 & 2.64 & 10.80 & 1.46 & 0.16 & 593 \\
\hline 2 & 1.28 & 3.96 & 12.80 & 1.73 & 0.15 & 1189 \\
\hline 3 & 2.32 & 4.08 & 14.25 & 2.03 & 0.16 & 2149 \\
\hline 4 & 2.52 & 4.68 & 9.00 & 1.85 & 0.28 & 4179 \\
\hline 5 & 2.48 & 4.91 & 3.51 & 1.97 & 0.76 & 9831 \\
\hline \multicolumn{7}{|l|}{ Sorting by region } \\
\hline Region & ZGDPC & ZJNHK & KH & KY & $\mathrm{HY}$ & GDPC \\
\hline OECD & 2.88 & 4.45 & 3.92 & 1.94 & 0.72 & 8615 \\
\hline LACAR & 1.55 & 2.32 & 11.25 & 1.95 & 0.18 & 3529 \\
\hline MENA & 2.08 & 6.26 & 10.55 & 1.71 & 0.15 & 4198 \\
\hline ASIA & 2.95 & 6.34 & 11.81 & 1.47 & 0.24 & 2438 \\
\hline AFRICA & 0.76 & 3.54 & 12.22 & 1.95 & 0.18 & 1287 \\
\hline \multicolumn{7}{|l|}{ Sorting by period } \\
\hline Period & ZGDPC & ZJNHK & KH & KY & HY & GDPC \\
\hline $61-65$ & 2.63 & 2.77 & 6.51 & 1.34 & 0.28 & 2436 \\
\hline $66-70$ & 3.33 & 4.60 & 8.83 & 1.53 & 0.27 & 2858 \\
\hline $71-75$ & 2.37 & 4.85 & 9.64 & 1.72 & 0.27 & 3468 \\
\hline $76-80$ & 2.20 & 5.22 & 9.91 & 1.95 & 0.32 & 3948 \\
\hline $81-85$ & -0.15 & 3.38 & 10.36 & 2.19 & 0.40 & 4151 \\
\hline $86-90$ & 0.53 & 2.97 & 9.76 & 2.20 & 0.46 & 4642 \\
\hline \multicolumn{7}{|c|}{$\begin{array}{l}\text { ZGDPC: Growth rate of per-capita GDP, in } 1985 \text { PPP dollars, from Heston-Summers. } \\
\text { ZJNHK: Growth rate of the stock of human capital. } \\
\text { KH: Ratio of physical capital to human capital. } \\
\text { KY: Ratio of physical capital to GDP. } \\
\text { HY: Ratio of human capital to GDP. }\end{array}$} \\
\hline
\end{tabular}


General patterns in the data are summarized in Figure 8 to Figure 11. Figure 8 is a plot of the log of the physical capital-output ratio against per capita GDP. Although there appears to be some convergence in the capital-output ratio as countries become wealthier, there is no particular trend. In contrast, Figure 9, which displays the log of the human capital-output ratio against percapita GDP, has a clear upward trend. ${ }^{5}$ This is new; it is no surprise that wealthy countries have absolutely more human capital than poorer countries, but this plot shows that richer countries also have relatively more human capital than poorer ones. Figure 10 presents this information in a slightly different way: the log of the ratio of human capital to physical capital is plotted against per-capita GDP. Again, the relative stock of human capital increases with GDP. These facts are not anticipated or explained by any of the new growth theory, as I will discuss later. Finally, Figure 11 plots of current education spending as a share of GDP against GDP growth. Note that no pattern is discernible here, which emphasizes the fact that current educational investment flows alone are a poor proxy for human capital accumulation, with its long time-to-build and slow depreciation.

${ }^{5} \mathrm{An}$ ordinary least squares regression of the log of the ratio of per capita human capital to per-capita GDP on a constant and per-capita GDP in thousand dollars yields a slope coefficient of 0.18 and a T-statistic of 21.8 . 


\section{E. Combining Data on Physical and Human Capital Stocks and Returns}

We now have data for the second ratio for the expression in Equation (9). We can now use the stock and return data to estimate the ratio of the Cobb-Douglas production function coefficients and check to see how closely they coincide with the coefficients from the growth decomposition. The average physical-human capital ratio across all available observations is 8.42. More importantly, the ratio of returns to physical and human capital is inversely related to the ratio of their stocks, which is what we would need for the ratio of the coefficients in the production function to be constant. The intersection of available data for all of these quantities is quite limited, but the relation is reasonably robust. A regression implied by Equation (9) yields positive and significant coefficients.

Recall Equation (9):

$$
\frac{r_{k}}{r_{h}}=\frac{\alpha}{\beta} \frac{H}{K}
$$

The regression form of this equation would be:

$$
\frac{r_{k}}{r_{h}}=b_{0}+b_{1} \frac{H}{K}+\epsilon
$$

Returns to education are reported for primary, secondary, and higher education. I construct a weighted average of the returns to all three levels of education by using their relative stocks as weights. I use the social returns to education since they include all costs of providing education. The regression from Equation (15) yields the parameter estimates displayed in Table 5. The slope coefficient is an estimate of the ratio of $\alpha$ to $\beta$. The coefficient estimate is about 3 , which implies that the ratio of $\alpha$ to $\beta$ should be about 3; more generally, the return and stock data for physical and human capital used in this regression equation suggest that the growth decomposition regression 
Table 5: Regressions of $R_{k} / R_{h}$ on $H / K$ and a constant

\begin{tabular}{||l|c|c||}
\hline \multicolumn{1}{|c|}{ Level of education } & Estimated $\mathrm{b}_{1}=\alpha / \beta$ & T-Statistic \\
\hline \hline Primary & 3.11 & 2.7 \\
\hline Secondary & 2.36 & 2.5 \\
\hline Higher & 3.40 & 4.2 \\
\hline Average & 3.24 & 2.5 \\
\hline
\end{tabular}

coefficient on physical capital should be substantially larger than that on human capital.

\section{Cross-Country Growth Regressions: Econometric Issues}

The relatively recent arrival of macro datasets covering a hundred or more countries and thirty to forty years has provided a rich source for empirical evidence on growth. However, many papers have ignored the time-series aspect of these new datasets to focus on time averages for each country. ${ }^{6}$ Although this approach has a certain appeal for the study of long-term growth, it wastes a great deal of the information that these datasets have to offer. Regression estimates obtained with time averages can be at best consistent and never efficient. In addition, neglect of the panel aspect of the data can conceal specification problems.

\section{A. Panel Estimation}

Hausman (1978) describes a simple, efficient estimator for panel data with individual effects. This estimator is consistent and efficient under the null hypothesis that the country-specific error

${ }^{6}$ These include, among many others, Mankiw, Romer, and Weil (1992) and Levine and Renelt (1991). 
component is not correlated with the right-hand side variables. Hausman and Taylor (1981) describe a simple test for the null hypothesis and propose an instrumental variables estimator for the parameters on the time-invariant variables if the null is rejected.

Following Hausman and Taylor (1981), we begin with a model for a dataset with T observations each from $\mathrm{N}$ countries where the error term consists of a random error term and a country-specific error term:

$$
Y_{i t}=X_{i t} \beta+Z_{i} \gamma+\alpha_{i}+\eta_{i t}
$$

The $\mathrm{Z}$ variables are time-invariant and the $\mathrm{X}$ variables vary with time. Under the null hypothesis that the country-specific errors are not correlated with the right-hand side variables, we can use a "random effects" specification. For this specification, a pooled regression is consistent but not efficient because it fails to take account of the serial correlation of the errors.

The "between" estimator is:

$$
\begin{gathered}
Y_{i .}=X_{i .} \beta+Z_{i .} \gamma+\alpha_{i}+\eta_{i .}, \\
Y_{i .} \equiv \sum_{t=1}^{T} Y_{i t}, X_{i .} \equiv \sum_{t=1}^{T} X_{i t}, Z_{i .} \equiv Z_{i}
\end{gathered}
$$

This is the group averages estimator most commonly used for cross-country regressions. Under the null hypothesis, this estimator will be unbiased but not efficient.

The data for the "within" estimator are constructed as deviations from group means:

$$
\left(Y_{i t}-Y_{i}\right)=\left(X_{i t}-X_{i}\right) \beta+\eta_{i t}
$$

This is identical to OLS with a dummy variable for each country. Here the country-specific error term disappears so that the estimator is consistent whether or not the null hypothesis holds. For time- 
varying variables, it is also efficient under the null. However, the $\gamma$ coefficients on time-invariant variables cannot be estimated.

Under the null hypothesis of random effects, the residuals from the between and within estimators can be used to construct an estimate of the variance matrix of the errors. This matrix can then be used in a generalized least squares (GLS) transformation, which turns out to be a linear transformation of the data. Thus, the efficient GLS estimator is obtained by calculating a weight, $\theta$, and performing ordinary least squares on

$$
Y-\theta Y_{i .}=\left(X-\theta X_{i}\right) \beta+\epsilon
$$

The null hypothesis of random effects can be tested by comparing the "between" and "within" estimates. Under the null, both the between and the within estimates are consistent, but under the alternative, the within estimate is consistent but the between is not. Since the estimators are orthogonal, the variance-covariance matrix of the difference between the between and the within is the difference of the variance-covariance matrices for the time-varying variables. Below, I report results of estimation of three major growth regression specifications using this framework. In general, I find that the pooled (OLS) estimates are quite close to the GLS estimates and that the null hypothesis of random effects cannot be rejected.

\section{A. The Reduced Form}


The reduced form is widely used. It relies on a model of the following form:

$$
\begin{aligned}
& \frac{\dot{Y}}{Y}=\beta_{0}+\beta_{1} \frac{\dot{K}}{K}+\beta_{2} \frac{\dot{L}}{L}+\beta_{3} \frac{\dot{H}}{H}+\epsilon \\
& \frac{\dot{K}}{K}=X_{K} \gamma_{1}+\epsilon_{k} \\
& \frac{\dot{L}}{L}=X_{L} \gamma_{2}+\epsilon_{l} \\
& \frac{\dot{H}}{H}=X_{H} \gamma_{3}+\epsilon_{h}
\end{aligned}
$$

If the $\mathrm{X}$ variables do not include output, capital, labor, or human capital, then the reduced form of the system is simply

$$
\frac{\dot{Y}}{Y}=X_{K} \gamma_{1}+X_{L} \gamma_{2}+X_{H} \gamma_{3}+\epsilon
$$

This is the reduced form often used. The coefficients measure the net effect of the variables on growth; the variables implicitly act by affecting the accumulation of labor, physical capital, and human capital. Reduced form estimation also yields low coefficient values for human capital; see Rows 3 to 5 of Table 1 . However, since the coefficients from such regressions do not have a clear interpretation in the context of the extended Solow model, I do not do any further tests.

\section{B. Mankiw, Romer, and Weil's Specification}

MRW propose an extension of the Solow model in which the production function is CobbDouglas in physical capital, labor, and human capital. They conjecture that the coefficient on human capital growth is around 0.3. To estimate the human capital parameter using only investment rates, 
they derive an approximation for steady-state income as a function of investment rates:

$$
\left.\ln \left(y_{t}\right)=\ln \left(A_{0}\right)+g t-\frac{\alpha+\beta}{1-\alpha-\beta} \ln (n+g+\delta)+\frac{\alpha}{1-\alpha-\beta} \ln \left(s_{k}\right)+\frac{\beta}{1-\alpha-\beta}(2)_{h}\right)\left(s_{h}\right)
$$

where $\mathrm{y}$ is per capita GDP, $\mathrm{t}$ is time, $\mathrm{n}$ is population growth, $\delta$ is depreciation, and $\mathrm{s}_{\mathrm{k}}$ and $\mathrm{s}_{\mathrm{h}}$ are savings rates for physical and human capital. They assume that $g+\delta=0.05$. Using this equation and secondary school enrollment as a proxy for human capital accumulation, they estimate the equation using the group-averages "between" estimator. Their estimation implies a human capital coefficient of approximately 0.3 , as expected.

However, this specification has four major problems. First, it does not exploit the panel aspect of the data. Second, the assumption that all economies were in steady state in 1985 is dubious at best, especially for less-developed countries. Third, the assumption that $\mathrm{g}+\delta=0.05$ is clearly too restrictive: population growth varies systematically across countries by stage of development, and there is no evidence that the depreciation rate varies inversely with g. Fourth, the assumption that secondary enrollment ratios are collinear with human capital accumulation is hazardous: in steady state it might be an acceptable approximation, but in countries where enrollments and human capital stocks are changing (which are nearly all of the countries in the sample), secondary enrollment is probably a bad approximation for two reasons. First, more secondary enrollment becomes more human capital only with a lag of several years. Second, without other information about the existing stock of human capital in an economy, the level of secondary enrollment says little about the rate at which human capital is accumulating. Countries with large human capital stocks and high secondary enrollment could be providing only a small increment to their capital stocks whereas countries with low human capital stocks and moderate secondary enrollment could be augmenting their capital stocks by large amounts. Thus, althought Mankiw, Romer, and Weil (1992) obtain a large and significant 
coefficient for human capital, they do so only with the help of some very strong assumptions.

\section{The Growth Decomposition Specification}

Other researchers, most notably Lau, Jamison, and Louat (1990) and the World Development Report (1991), have focused on the growth decomposition of the Cobb-Douglas production function used by Mankiw, Romer, and Weil (1992). The coefficient estimates they obtain for human capital are difficult to compare and interpret because they rarely use percentage changes of human capital stock as the human capital accumulation variable. The World Development Report (1991) uses a pooled panel regression specification with a dataset that covered 68 less developed countries over 30 years. He calculates growth rates of physical capital from a new capital stock series and uses the World Bank's series on the average education of the labor force to measure human capital stock accumulation. It uses the absolute change in human capital stock measured in average years of educational attainment of the labor force, which yields the results reported in Row 6 of Table 1 . However, when percentage changes are used and are constrained to be the same for all levels of education, the coefficient becomes negative and insignificantly different from zero. Benhabib and Spiegel (1991) use a different dataset that also measures the average educational attainment of the labor force but also obtain a negative coefficient on human capital. Using absolute changes in education, they obtain a coefficient of $-0.021(\mathrm{~T}=1.4)$; see Row 7 of Table 1. Finally, Lau, Jamison, and Loaut (1991) obtain a low and insignificant, but positive coefficient of 0.016 (T=1.6); see Row 8 of Table 1. Since these studies use data and methods at least as thorough as those of MRW, and since we generally believe that human capital accumulation contributes to growth, these low coefficient values are quite puzzling.

I focus on the growth decomposition specification for two reasons. First, it provides some 
structure and interpretation for the coefficients without requiring too many compromises or assumptions. Second, the parameter estimates have straightforward interpretations which can be compared to other information and measurements about relative stocks and returns for human and physical capital.

\section{Performance in Cross Country Regressions}

I demonstrate the behavior of my new human capital series in two major types of regression specification: the production function-based growth decomposition regression of GDP growth on capital, labor, and human capital growth; and the reduced form regression of GDP growth on inflation, human capital levels and growth, and other policy measures. In both forms, the human capital coefficient is positive and statistically significant; the magnitude is around 0.10 , greater than 
Table 6: Growth Decomposition Regression Results

\begin{tabular}{|c|c|c|c|c|c|}
\hline \multicolumn{6}{|c|}{ Dependent variable is per-worker GDP*100 } \\
\hline \multicolumn{2}{|c|}{ Variable } & Pooled & Between & Within & GLS \\
\hline \multirow[t]{2}{*}{ ZKAPL } & Coeff & 38.811 & 30.784 & 43.130 & 39.100 \\
\hline & T-Stat & 12.614 & 5.834 & 11.031 & 9.916 \\
\hline \multirow[t]{2}{*}{ ZHKL } & Coeff & 9.279 & 12.771 & 8.790 & 9.261 \\
\hline & T-Stat & 4.809 & 3.367 & 3.907 & 3.886 \\
\hline \multirow[t]{2}{*}{ CONST } & Coeff & -0.200 & -0.057 & & -0.223 \\
\hline & T-Stat & -1.000 & -0.195 & & -1.555 \\
\hline \multicolumn{6}{|c|}{$\begin{array}{ll}\mathrm{N}=312 \quad \text { Number of countries }=70 & \mathrm{R}^{2}=0.79 \\
\mathrm{D}-\mathrm{W}=2.16 \text { and } \rho=-0.08 & \end{array}$} \\
\hline \multicolumn{6}{|c|}{$\begin{array}{l}\text { Countries used in this regression (grouped by continent): } \\
\text { DZA CMR ETH GHA CIV KEN MDG MWI MUS MAR NGA RWA SEN } \\
\text { SLE TZA UGA ZAR ZMB ZWE CRI SLV GTM HTI HND JAM MEX PAN } \\
\text { USA ARG BOL CHL COL ECU PRY PER URY VEN BGD BUR CHN IND } \\
\text { IDN IRN ISR JPN KOR MYS PAK PHL SGP LKA THA AUT BEL DNK } \\
\text { FIN FRA DEU GRC IRL ITA NLD NOR PRT ESP SWE CHE TUR GBR }\end{array}$} \\
\hline
\end{tabular}

that found by the authors mentioned above but still substantially less than MRW's 0.3 .

Table 6 presents complete results for my estimates of the growth decomposition specifications; 
Table 7: Reduced Form Regression Results

\begin{tabular}{|c|c|c|c|c|c|}
\hline \multicolumn{6}{|c|}{ Dependent variable is GDP growth rate*100 } \\
\hline Variable & & Pooled & Between & Within & GLS \\
\hline \multirow[t]{2}{*}{ ZHK } & Coeff & 15.329 & 22.409 & 12.537 & 14.990 \\
\hline & T-Stat & 6.771 & 5.255 & 4.717 & 6.170 \\
\hline \multirow[t]{2}{*}{ CONST } & Coeff & 3.125 & 2.654 & . & 3.142 \\
\hline & T-Stat & 14.123 & 8.070 & . & 14.494 \\
\hline \multicolumn{6}{|c|}{$\begin{array}{l}\mathrm{N}=332 \text {. Number of countries }=75 . \quad \mathrm{D}-\mathrm{W}=1.72, \mathrm{rho}=0.14 \text {. } \\
\mathrm{F}(75,330) \text { for significance of dummies }=1.58 \\
\text { Hausman test statistic for } \mathrm{H} 0: \mathrm{E}(\mathrm{a} \mid \mathrm{x}, \mathrm{z})=0 \text { is } 3.86, \mathrm{p}=0.05 \\
\mathrm{R}^{2}=0.73\end{array}$} \\
\hline \multicolumn{6}{|c|}{$\begin{array}{l}\text { Countries in this regression are: } \\
\text { DZA CMR ETH GHA CIV KEN MDG MWI MLI MUS MAR NGA RWA SEN } \\
\text { SLE SDN TZA TUN UGA ZAR ZMB ZWE CRI SLV GTM HTI HND JAM } \\
\text { MEX PAN USA ARG BOL CHL COL ECU PRY PER URY VEN BGD BUR } \\
\text { CHN IND IDN IRN IRQ ISR JPN KOR MYS PAK PHL SGP LKA SYR THA } \\
\text { AUT BEL DNK FIN FRA DEU GRC IRL ITA NLD NOR PRT ESP SWE CHE } \\
\text { TUR GBR }\end{array}$} \\
\hline
\end{tabular}

Table 7 presents results for the reduced-form regression. T-statistics are in parentheses underneath the coefficient estimates; the GLS standard errors have been computed using the Newey and West (1987) method for estimating standard errors that are robust to serial correlation and heteroskedasticity. Note that the T-statistic indicates that the coefficient on human capital growth is significantly different from zero. The Hausman test statistic indicates that the null hypothesis of random effects cannot be rejected at the 5\% level; we conclude that the GLS estimator is efficient. 
Table 8: List of Variables Used for Panel Regressions

\begin{tabular}{||l|l||}
\hline \hline ZGDPT & $\begin{array}{l}\text { Percentage growth rate of total GDP in } 1985 \text { PPP dollars, from Heston- } \\
\text { Summers (1992), multiplied by 100. }\end{array}$ \\
\hline ZKAP & $\begin{array}{l}\text { Percentage growth rate of the capital stock, from Nehru (1992). The } \\
\text { series is calculated using the perpetual inventory method and an initial } \\
\text { stock of zero. The measurements are in } 1987 \text { national currency units. } \\
\text { To link the human capital measured in 1985 prices with the physical } \\
\text { capital measured in 1987 prices, I use the GDP deflator implied by the } \\
\text { ratio of nominal to real GDP in 1987 as reported by the IMF. } \\
\text { Observations for which the annual growth rate exceeds 30\% are } \\
\text { excluded. }\end{array}$ \\
\hline ZLAB & $\begin{array}{l}\text { Percentage growth rate of the labor force, from the World } \\
\text { Development Report (1991) dataset and OECD Labor Force Statistics. }\end{array}$ \\
\hline ZHK & $\begin{array}{l}\text { Percentage growth rate of my measure of human capital, using Nehru's } \\
\text { educational attainment series. Observations for which the annual } \\
\text { growth rate exceeds 30\% are excluded. }\end{array}$ \\
\hline CONST & Constant \\
\hline \hline
\end{tabular}

Table 8 summarizes the variables I use in the regressions. In the second set of regressions, the reduced-form model, the human capital coefficient is fifty percent larger, 0.15 , than in the growth decomposition regressions. But the interpretation is less straightforward: the coefficient reflects the raw comovement of human capital growth and output growth without accounting for growth in other inputs, such as physical capital.

\section{E. Conclusions}

Panel generalized least squares estimation of the extended Solow model decomposition of growth using a new measure of human capital stock yields a human capital coefficient of about 0.1 and a physical capital coefficient of about 0.4. These coefficient estimates fit well with other 
evidence about the relative stocks and rates of return to human and physical capital. The coefficient estimates give us the first ratio of the relation from Equation (9) as about 4. Thus, we now have:

$$
\frac{r_{h}}{r_{k}}=\frac{\beta}{\alpha} \frac{K}{H} \Leftrightarrow \frac{r_{h}}{r_{k}}=\frac{.1}{.4} \frac{K}{H} \Leftrightarrow \frac{K}{H}=4 \frac{{ }^{r}}{r_{k}}
$$

Recall that, on average, the ratio of human capital returns to physical capital returns is about 2, and the average ratio of physical to human capital is 8 . Further, recall that the regressions based on Equation (9) predicted a ratio of the capital to human capital coefficient of about 3.

\section{F. Productivity Residuals}

The residuals from these panel regressions can be interpreted as productivity residuals, or the part of growth that comes not from raw factor accumulation, but from productivity gains. In Appendix 1, I display average productivity residuals for each country over the whole time period, grouped by region and ranked from lowest to highest. The region averages are weighted by the number of observations available for each country. Note that the average residual is lowest for Africa and highest for Asia. Of the four rapidly growing Asian economies, I have data for only two, Singapore and Korea. Singapore has a negative productivity residual (-0.6) while Korea's is positive (1.1).

\section{Human Capital and the New Growth Theory}

Many models have been developed to incorporate the special nature of human capital into the production function. However, none has predicted the strong relationship between $\mathrm{H} / \mathrm{Y}$, the human capital-output ratio, and the level of output. Where models are fully elaborated, predictions about the 
interaction of levels, growth, and returns to human and physical capital are discussed in a general way. If any evidence on human capital is presented, the human capital variable is usually literacy or, in some of the newer work, average years of education of the labor force. Very few, if any, of the implications of these models are borne out by the data, as we shall now see.

Azariadis and Drazen propose a model in which there are threshold externalities to the accumulation of human capital. The primary predictions of their model are that returns to human capital should rise as human capital stocks increase, and that countries with higher stocks of human capital relative to income should grow faster. Neither of these predictions holds. Returns to human capital decline as income (and stocks of human capital) increase (see Figure 1 to Table 9). Further, there is no direct relationship between $\mathrm{H} / \mathrm{Y}$ and growth, as can be seen from Figure 12.

Barro and Sala-i-Martin (1993) review a series of models in which the production function has inputs of capital and labor, and capital stocks cannot adjust instantaneously. They review many cases; in all of them, the expected path of $\mathrm{H} / \mathrm{Y}$ and $\mathrm{H} / \mathrm{K}$ does not match the results $\mathrm{I}$ find. In particular, the models they present all predict a U-shaped relationship between $\mathrm{K} / \mathrm{H}$ and growth, which does not appear; see Figure 13. Further, they make no predictions about the relationship between $\mathrm{H} / \mathrm{Y}$ and $\mathrm{Y}$. Their model includes Lucas's (1988) model as a special case.

Jovanoviç, Lach, and Lavy (1992) come closest to providing a solution to the low coefficient puzzle. They develop a model in which human capital raises future output rather than current output. In such a model, the elasticity of output with respect to current human capital can be low even if the share of human capital in output is high. They estimate the share of human capital alone in output to be on the order of $60 \%$. They find some regression results consistent with their theory. In their growth decomposition regressions, they find negative or insignificantly positive coefficients for human capital, relatively high coefficients for physical capital (0.48), and also high coefficients for labor 
(0.50). The high labor coefficient is a problem for them since labor has a very small share of output in their model. In addition, their estimation clearly does not capture the significant, albeit relatively small, role of human capital in current production.

Romer (1990) proposes a model in which economies produce many goods and the role of human capital is to introduce new goods. He finds that the level of literacy is positively correlated with investment but not with growth. His idea, however, seems to fit the results I find in a regression that includes separate human capital coefficients for each level of education and for different levels of initial income. The estimation results for this regression are displayed in Table 9. In this regression, only primary education matters for low-initial-GDP countries, but only higher education matters for high-initial-GDP countries. Thus, although Romer's own results are not particularly strong, his model does fit with my findings.

Finally, the only alternative production function that fits with the finding that $\mathrm{H} / \mathrm{Y}$ increases with Y is Fallon and Layard (1975). They investigate a production function in which capital is more complementary to human capital than to raw labor. In this case, the share of income from human capital increases with GDP. They test their hypothesis with cross-country wage data and a two-level CES function. The nested two-level CES function can be estimated in a growth decomposition form similar to that used for the Cobb-Douglas production function except that the resulting equation is nonlinear. Since the Cobb-Douglas production function is a special case of the CES and nested CES, it is easy to test the restrictions implied by the Cobb-Douglas. Using macro data, I find that human capital is indeed more complementary to physical capital than is raw labor. However, while the elasticity coefficients are significantly different from zero (the Cobb-Douglas case) and each other, their magnitude is not very far from zero: the coefficient estimates imply elasticities of about 1.2 a $\quad \mathrm{t} \quad \mathrm{h} \quad \mathrm{e} \quad \mathrm{r}$

$\mathrm{t} \quad \mathrm{h} \quad \mathrm{a} \quad \mathrm{n}$ $1 \quad$. 
Table 9: Panel Regression with Education Levels Entering Separately and Interacted Dummies for Initial Income

\begin{tabular}{|c|c|c|c|c|c|}
\hline \multicolumn{6}{|c|}{$\begin{array}{l}\text { Dependent variable is ZGDPL*100 } \\
\text { Income breaks are at } 1025,1903 \text {, and } 4266 \text { (1985 PPP dollars) }\end{array}$} \\
\hline \multicolumn{2}{|l|}{ Variable } & \multirow{2}{*}{$\begin{array}{r}\text { Pooled } \\
40.422 \\
13.028\end{array}$} & \multirow{2}{*}{$\begin{array}{r}\text { Between } \\
33.426 \\
5.609\end{array}$} & \multirow{2}{*}{$\begin{array}{r}\text { Within } \\
43.089 \\
11.345\end{array}$} & \multirow{2}{*}{$\begin{array}{r}\text { GLS } \\
40.933 \\
8.839\end{array}$} \\
\hline ZKAP & $\begin{array}{l}\text { Coeff } \\
\text { T-Stat }\end{array}$ & & & & \\
\hline ZHKP1 & $\begin{array}{l}\text { Coeff } \\
\text { T-Stat }\end{array}$ & $\begin{array}{r}10.624 \\
4.249\end{array}$ & $\begin{array}{l}2.784 \\
0.699\end{array}$ & $\begin{array}{r}19.702 \\
5.381\end{array}$ & $\begin{array}{r}12.151 \\
1.151\end{array}$ \\
\hline ZHKS1 & $\begin{array}{l}\text { Coeff } \\
\text { T-Stat }\end{array}$ & $\begin{array}{l}0.986 \\
0.355\end{array}$ & $\begin{array}{l}6.157 \\
1.272\end{array}$ & $\begin{array}{l}-0.968 \\
-0.268\end{array}$ & $\begin{array}{l}0.563 \\
0.078\end{array}$ \\
\hline ZHKH1 & $\begin{array}{l}\text { Coeff } \\
\text { T-Stat }\end{array}$ & $\begin{array}{l}-2.574 \\
-1.387\end{array}$ & $\begin{array}{l}0.553 \\
0.105\end{array}$ & $\begin{array}{l}-3.273 \\
-1.671\end{array}$ & $\begin{array}{l}-2.719 \\
-1.219\end{array}$ \\
\hline ZHKP2 & $\begin{array}{l}\text { Coeff } \\
\text { T-Stat }\end{array}$ & $\begin{array}{r}10.144 \\
3.078\end{array}$ & $\begin{array}{r}14.767 \\
2.689\end{array}$ & $\begin{array}{l}7.455 \\
1.856\end{array}$ & $\begin{array}{l}9.774 \\
2.102\end{array}$ \\
\hline ZHKS2 & $\begin{array}{l}\text { Coeff } \\
\text { T-Stat }\end{array}$ & $\begin{array}{l}-1.111 \\
-0.457\end{array}$ & $\begin{array}{l}-5.563 \\
-0.997\end{array}$ & $\begin{array}{l}1.914 \\
0.659\end{array}$ & $\begin{array}{l}-0.665 \\
-0.211\end{array}$ \\
\hline ZHKH2 & $\begin{array}{l}\text { Coeff } \\
\text { T-Stat }\end{array}$ & $\begin{array}{l}0.165 \\
0.099\end{array}$ & $\begin{array}{l}1.415 \\
0.237\end{array}$ & $\begin{array}{l}0.749 \\
0.440\end{array}$ & $\begin{array}{l}0.267 \\
0.227\end{array}$ \\
\hline ZHKP3 & $\begin{array}{l}\text { Coeff } \\
\text { T-Stat }\end{array}$ & $\begin{array}{l}-2.328 \\
-0.685\end{array}$ & $\begin{array}{l}4.847 \\
0.627\end{array}$ & $\begin{array}{l}-6.241 \\
-1.568\end{array}$ & $\begin{array}{l}-3.312 \\
-0.575\end{array}$ \\
\hline ZHKS3 & $\begin{array}{l}\text { Coeff } \\
\text { T-Stat }\end{array}$ & $\begin{array}{l}3.340 \\
0.987\end{array}$ & $\begin{array}{l}1.718 \\
0.192\end{array}$ & $\begin{array}{l}8.957 \\
2.072\end{array}$ & $\begin{array}{l}4.265 \\
1.028\end{array}$ \\
\hline ZHKH3 & $\begin{array}{l}\text { Coeff } \\
\text { T-Stat }\end{array}$ & $\begin{array}{l}5.577 \\
2.518\end{array}$ & $\begin{array}{l}2.109 \\
0.248\end{array}$ & $\begin{array}{l}6.715 \\
2.996\end{array}$ & $\begin{array}{l}5.867 \\
1.288\end{array}$ \\
\hline ZHKP4 & $\begin{array}{l}\text { Coeff } \\
\text { T-Stat }\end{array}$ & $\begin{array}{l}-7.995 \\
-1.353\end{array}$ & $\begin{array}{r}-16.273 \\
-1.006\end{array}$ & $\begin{array}{l}-5.202 \\
-0.815\end{array}$ & $\begin{array}{l}-7.227 \\
-3.883\end{array}$ \\
\hline ZHKS4 & $\begin{array}{l}\text { Coeff } \\
\text { T-Stat }\end{array}$ & $\begin{array}{l}0.232 \\
0.053\end{array}$ & $\begin{array}{l}-3.636 \\
-0.463\end{array}$ & $\begin{array}{l}-3.134 \\
-0.490\end{array}$ & $\begin{array}{l}0.304 \\
0.068\end{array}$ \\
\hline ZHKH4 & $\begin{array}{l}\text { Coeff } \\
\text { T-Stat }\end{array}$ & $\begin{array}{r}12.671 \\
2.718\end{array}$ & $\begin{array}{r}23.839 \\
1.943\end{array}$ & $\begin{array}{l}8.231 \\
1.582\end{array}$ & $\begin{array}{r}11.591 \\
3.988\end{array}$ \\
\hline CONST & $\begin{array}{l}\text { Coeff } \\
\text { T-Stat }\end{array}$ & $\begin{array}{l}-0.324 \\
-1.533\end{array}$ & $\begin{array}{l}-0.140 \\
-0.401\end{array}$ & . & $\begin{array}{l}-0.376 \\
-1.651\end{array}$ \\
\hline $\begin{array}{l}\mathrm{N}=312 \\
\mathrm{D}-\mathrm{W}=2.0 \\
\text { Hausman }\end{array}$ & $\begin{array}{l}\text { mber of } \\
d \rho=-0 . \\
\text { statistic }\end{array}$ & $\begin{array}{l}\mathrm{s}=70 \quad \mathrm{R}^{2}=0 \\
: \mathrm{E}(\mathrm{a} \mid \mathrm{x}, \mathrm{z})=0\end{array}$ & $.67, p=0.080$ & & \\
\hline $\begin{array}{l}\text { Countries } \\
\text { Note: In } \\
\text { or } 4 \text { to in }\end{array}$ & in thi & $\begin{array}{l}\text { ion are the } \\
\text { es, } i \text { is } P(P \\
f \text { initial ince }\end{array}$ & $\begin{array}{l}\text { as those use } \\
\text { ), S (Secon } \\
\text { is lowest). }\end{array}$ & $\begin{array}{l}\text { able } 7 . \\
\text { or H (Highe }\end{array}$ & is $1,2,3$, \\
\hline
\end{tabular}


In sum, none of the new growth models can offer a superior description of the role of human capital in growth to the growth decomposition based on the extended Cobb-Douglas production function. The data either contradict their predictions or say nothing about them; none of them explain the unusual feature uncovered by a new measure of human capital stocks: the relationship between the human capital-output ratio and output is robustly positive.

\section{Conclusions: Education and Growth}

Sections II, III, and IV provide the three ratios that I relate in Equation (9). From this analysis I draw four main conclusions. First, the new human capital series provides adds to the evidence from Mankiw, Romer, and Weil (1992) that the extended Solow model provides a surprisingly good description of growth across countries and time. Second, however, the coefficient on human capital is much lower than 0.3 ; using a new human capital series, I estimate it to be 0.1 . Other relations implied by the Cobb-Douglas form support this estimate. Third, estimates of the stock 
of human capital indicate that in many economies it is scarce compared to physical capital. Fourth, the fact that the share of human capital in output increases systematically with wealth suggests that an ample supply of human capital is a necessary condition for economic development, although it is not clear whether rising human capital stocks are a cause or an effect of development.

The data also provide ample evidence that human capital accumulation patterns differ from those of physical capital, and they give us some important clues about where those differences lie. The most striking difference is that the stock of human capital relative to output and physical capital rises with wealth, while the physical capital-output ratio is essentially constant with respect to the level of GDP. This fact is neither predicted nor explained by any of the new growth models.

In sum, human capital cannot be ignored in growth decompositions and analyses of growth based on the Solow model: new measurements of human capital stock reveal a consistently significant coefficient on human capital accumulation of about 0.1 , or 10 percent. Thus, it is also an exaggeration to claim a role for human capital accumulation equal to that of physical capital, whose share in growth is between one third and one half. 


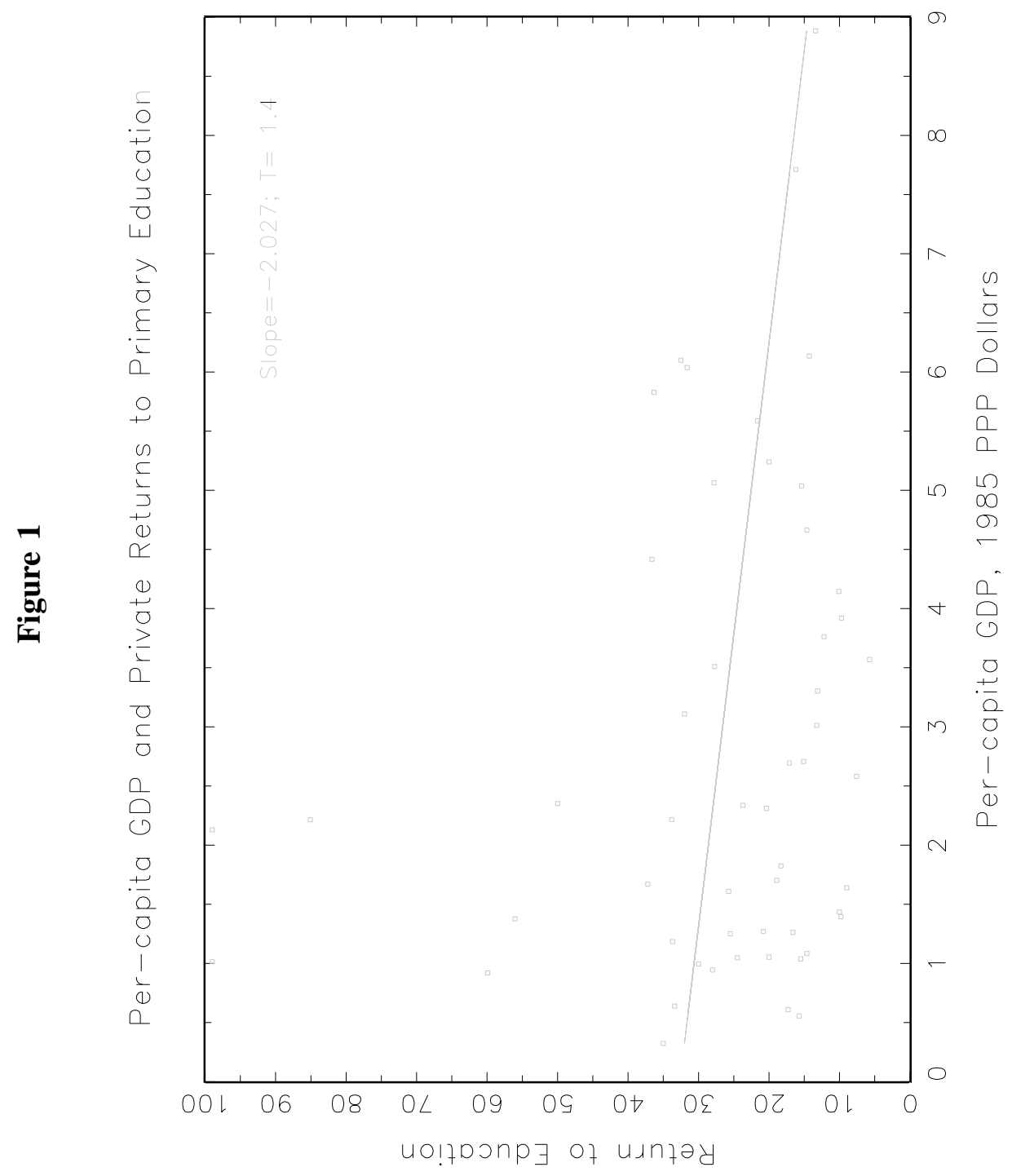




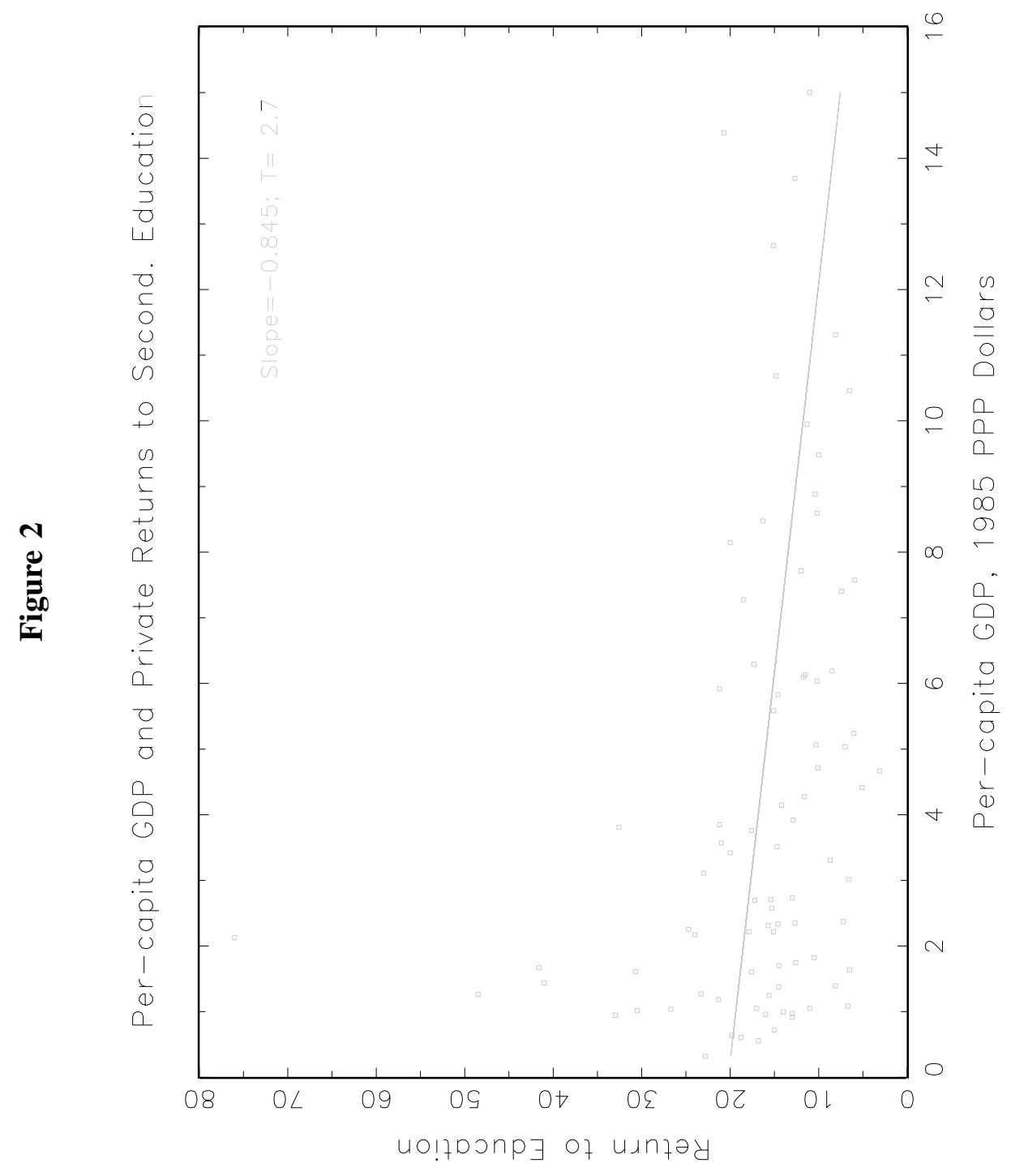




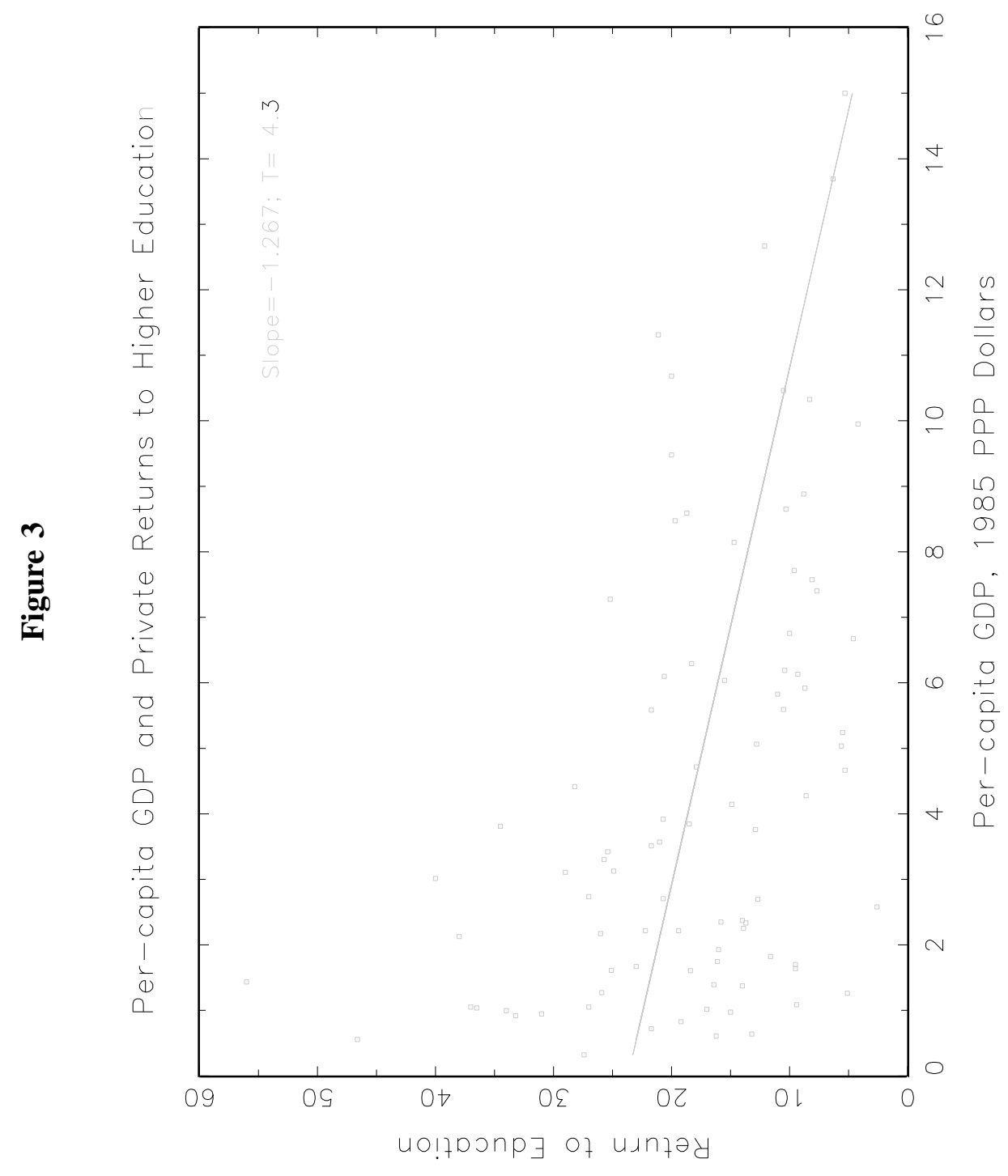




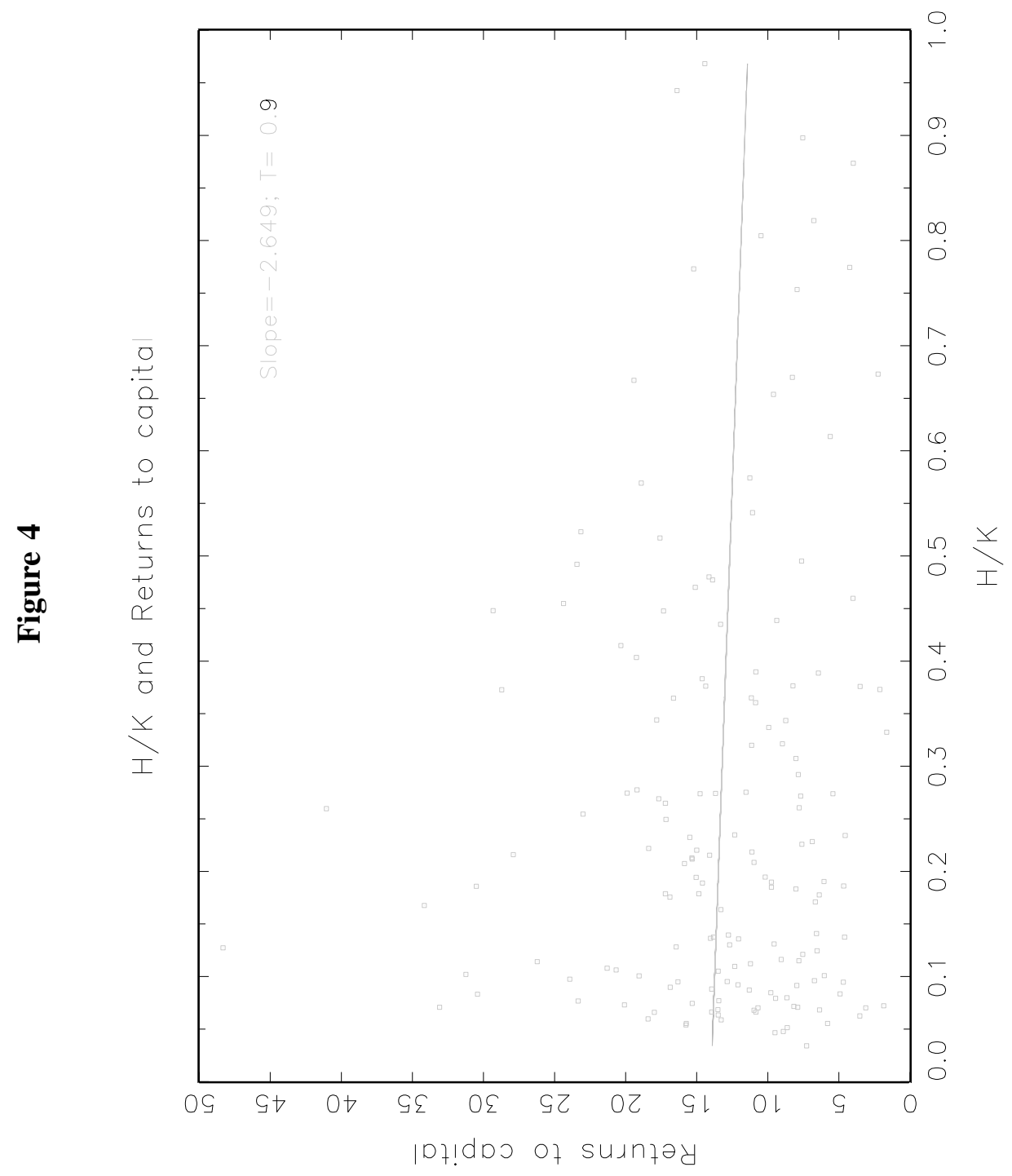




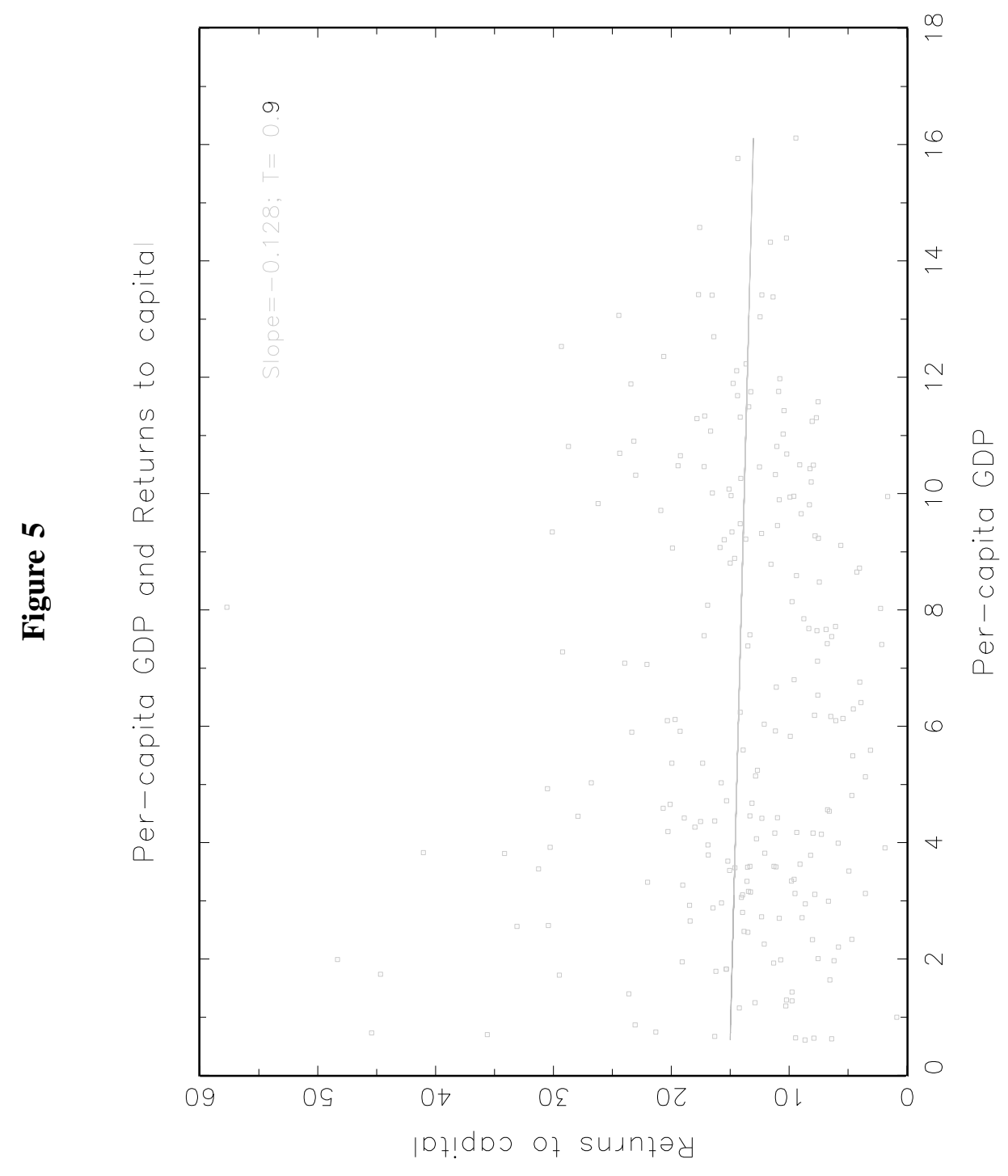




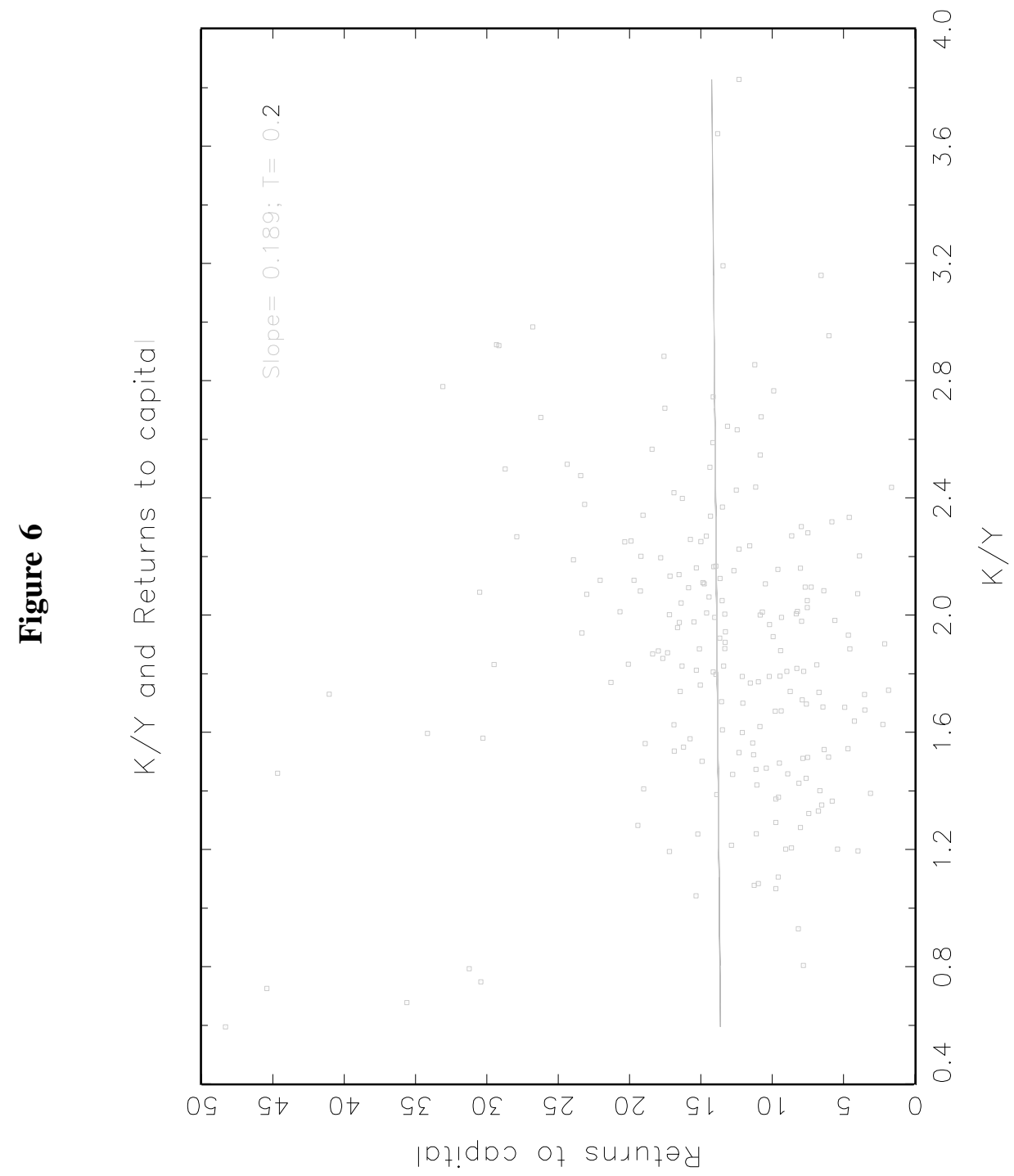




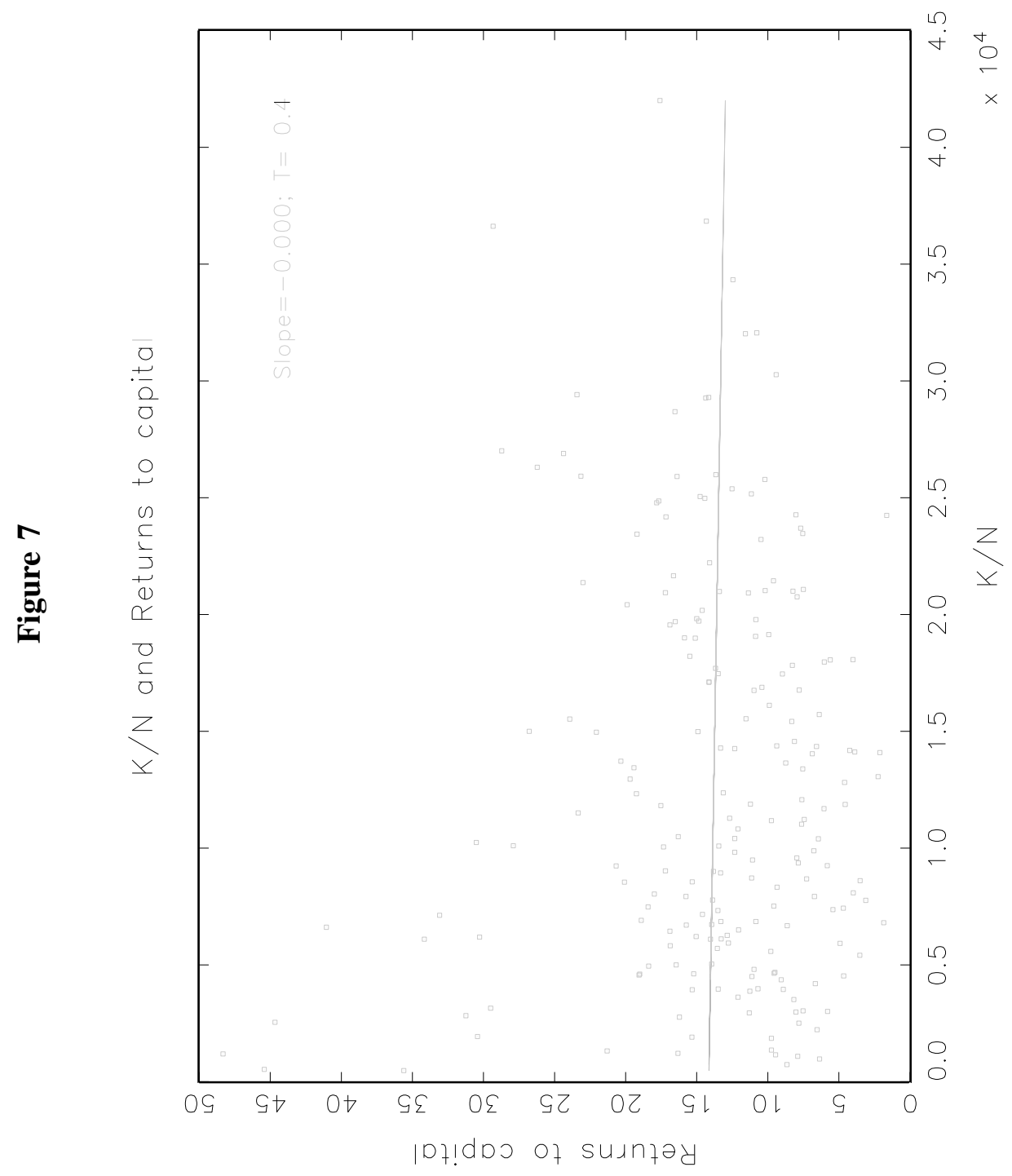




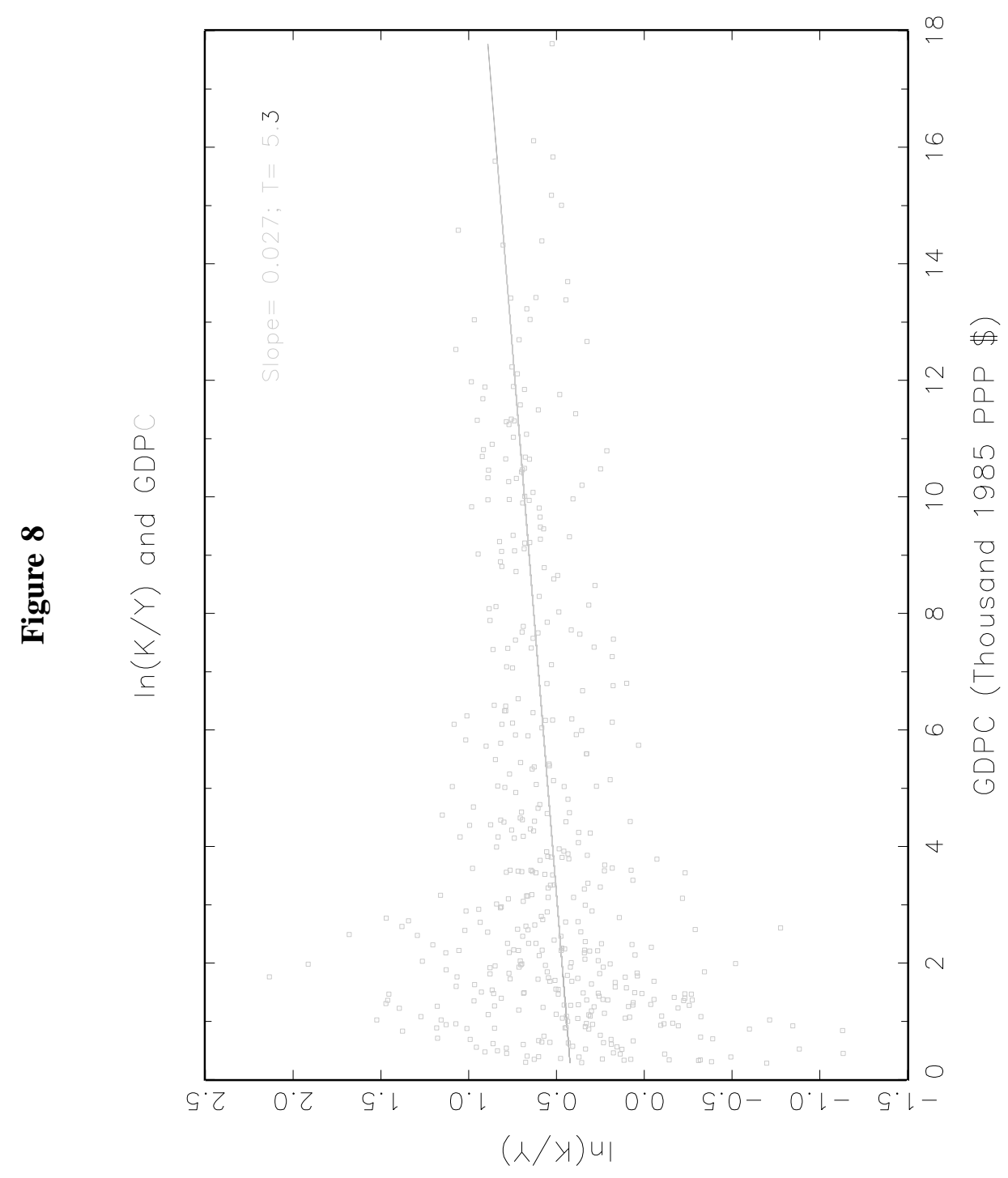




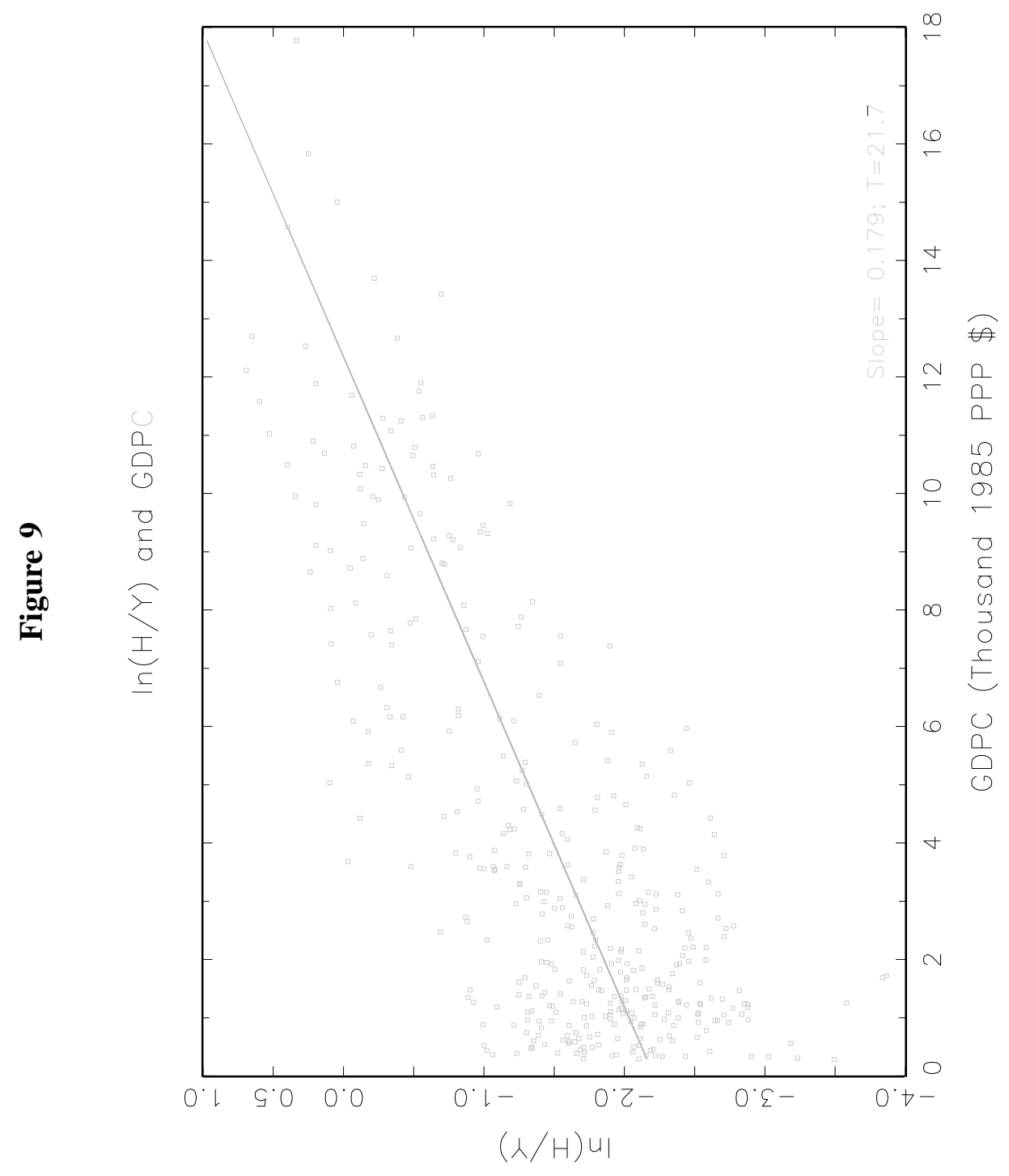




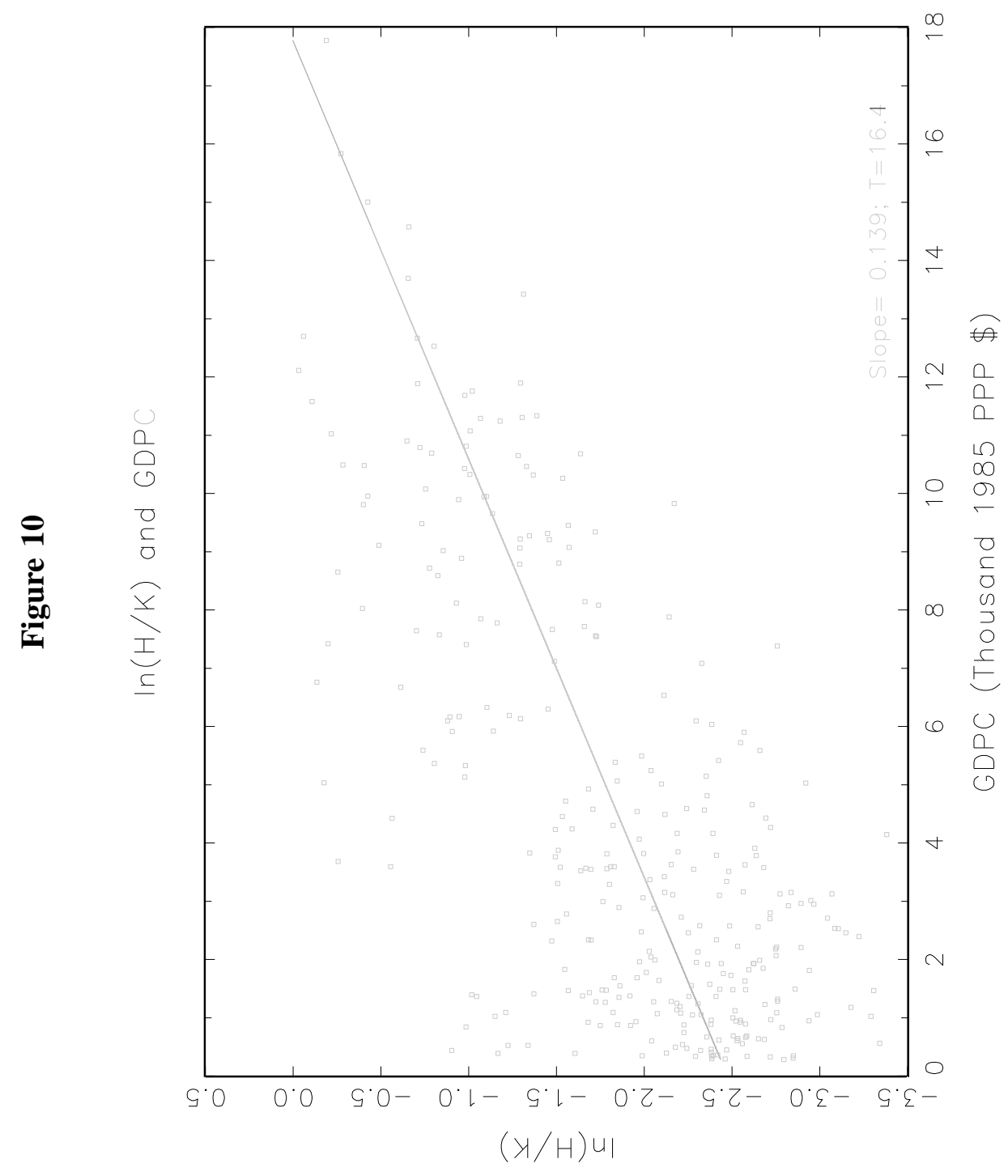




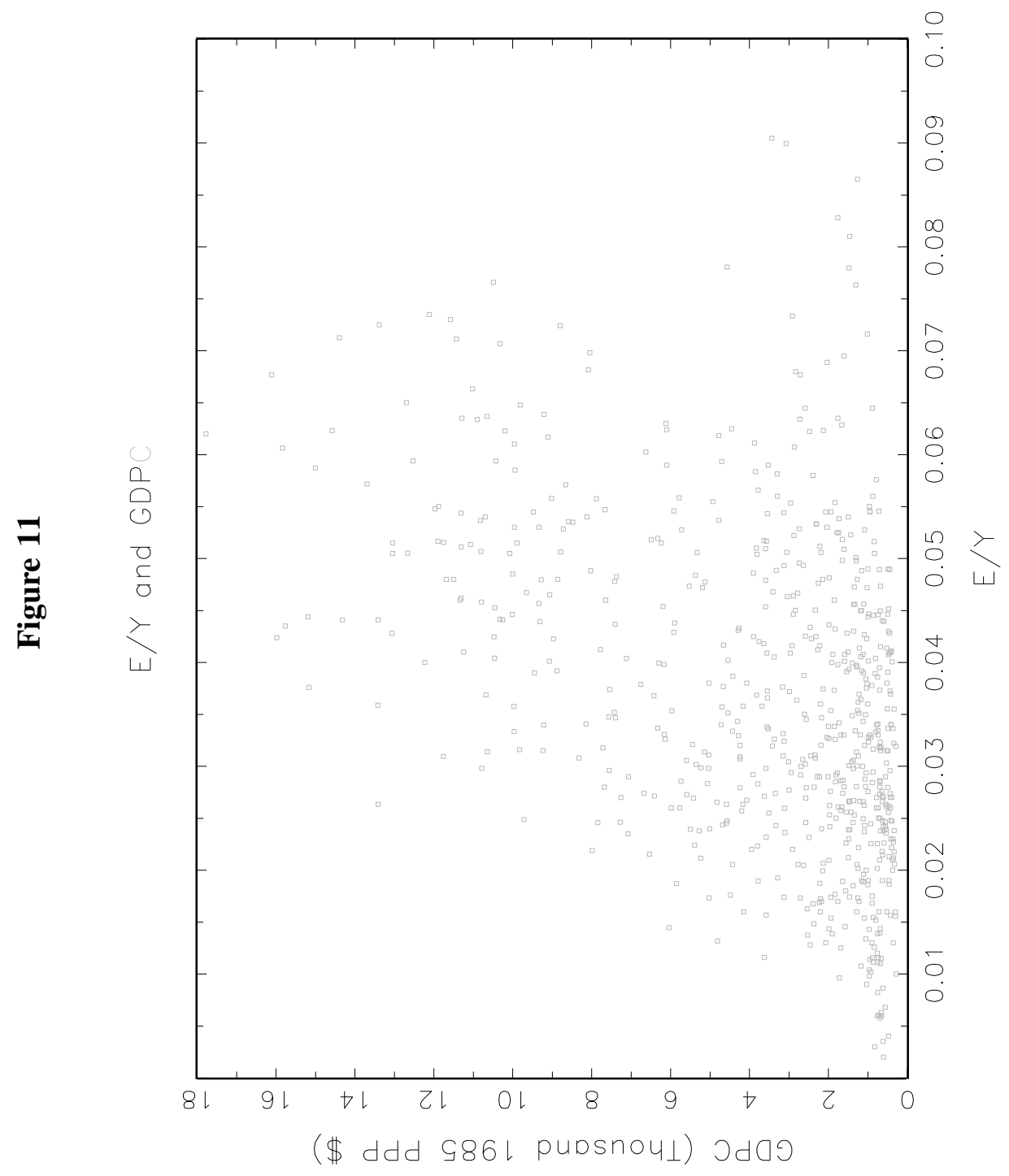




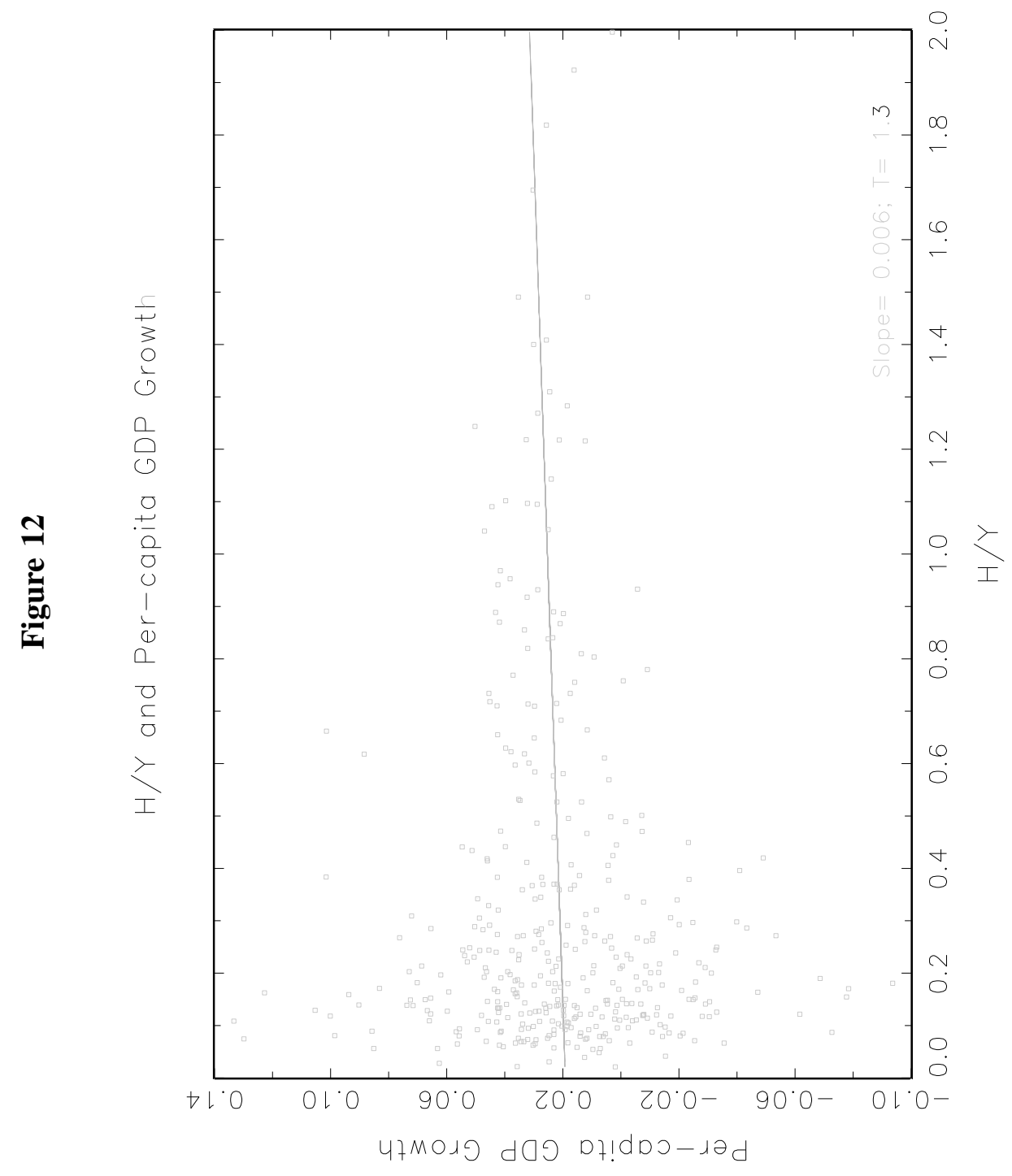




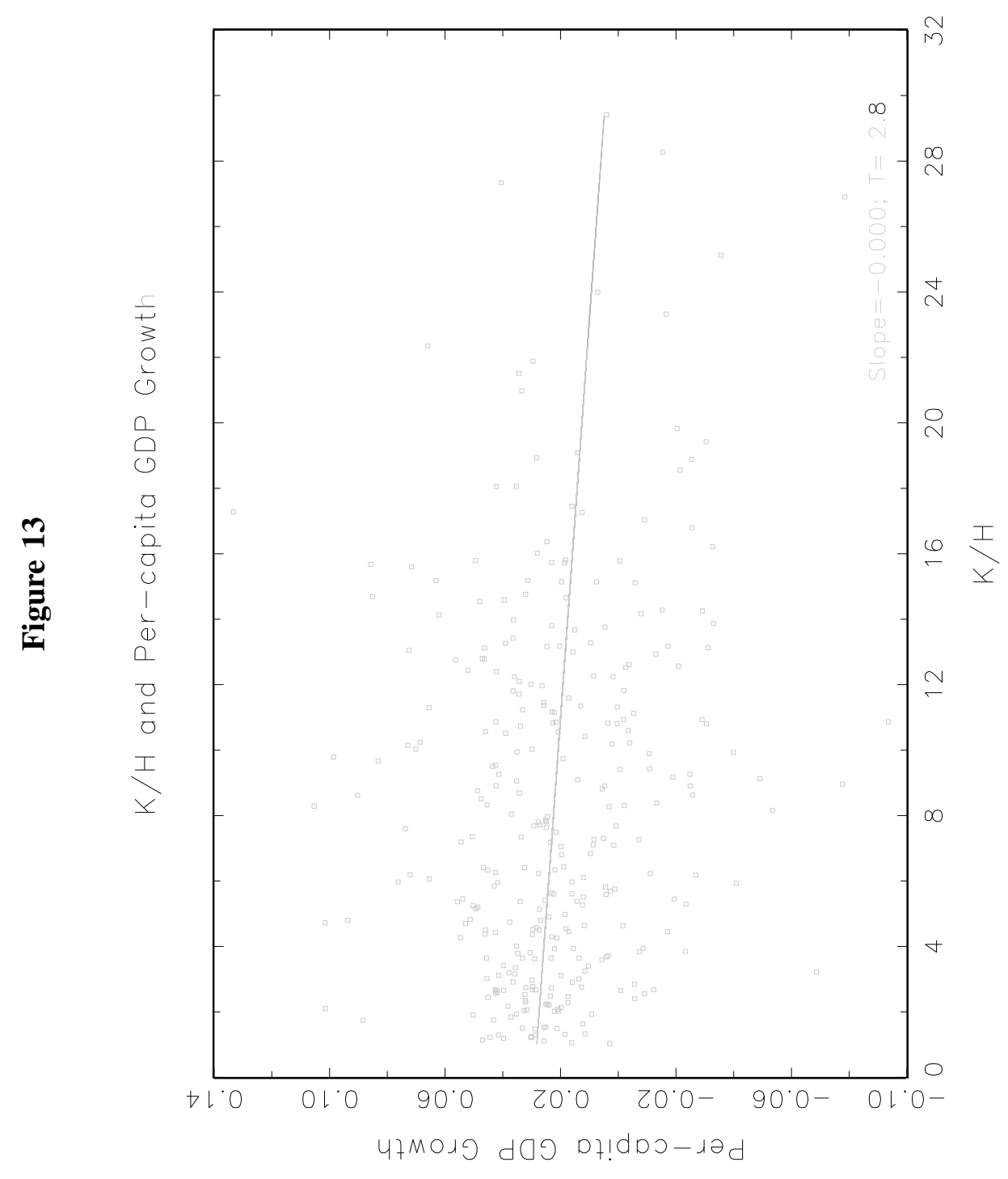


Appendix 1: Productivity Residuals

Region Averages and Rankings Within Regions

\begin{tabular}{||cc||}
\hline Country & Residual \\
\hline \hline For OECD, average residual is & -0.01 \\
\hline NZL & -1.8 \\
DNK & -0.7 \\
ESP & -0.6 \\
CHE & -0.4 \\
IRL & -0.3 \\
SWE & -0.3 \\
GBR & -0.2 \\
NLD & -0.2 \\
PRT & -0.1 \\
FRA & 0.0 \\
USA & 0.0 \\
DEU & 0.0 \\
BEL & 0.2 \\
GRC & 0.3 \\
AUT & 0.4 \\
NOR & 0.5 \\
FIN & 0.7 \\
ITA & 1.1 \\
TUR & 1.3 \\
\hline For LACAR, average residual is 0.06 \\
\hline \hline HTI & -3.4 \\
SLV & -1.2 \\
CHL & -1.2 \\
JAM & -0.6 \\
ARG & -0.1 \\
URY & -0.0 \\
PER & 0.0 \\
CRI & 0.1 \\
MEX & 0.3 \\
PAN & 0.3 \\
GOL & 0.4 \\
HRY & 0.5 \\
\hline & 0.5 \\
HND & 1.0 \\
\hline \hline
\end{tabular}




\begin{tabular}{|c|c|}
\hline Country & Residual \\
\hline \multicolumn{2}{|c|}{ For EMENA, average residual is 0.36} \\
\hline IRN & -2.3 \\
\hline MAR & -0.7 \\
\hline ISR & 1.2 \\
\hline DZA & 3.1 \\
\hline \multicolumn{2}{|c|}{ For ASIA, average residual is 0.42} \\
\hline LKA & -0.8 \\
\hline SGP & -0.6 \\
\hline BGD & -0.5 \\
\hline MYS & -0.2 \\
\hline IND & 0.0 \\
\hline BUR & 0.0 \\
\hline PHL & 0.3 \\
\hline PAK & 0.5 \\
\hline JPN & 0.9 \\
\hline THA & 0.9 \\
\hline IDN & 1.0 \\
\hline KOR & 1.1 \\
\hline $\mathrm{CHN}$ & 2.7 \\
\hline \multicolumn{2}{|c|}{ For AFRICA average residual is -0.53} \\
\hline NGA & -3.2 \\
\hline SLE & -3.0 \\
\hline MDG & -2.5 \\
\hline ZMB & -2.5 \\
\hline RWA & -2.1 \\
\hline ZAR & -2.1 \\
\hline SEN & -2.1 \\
\hline CIV & -1.6 \\
\hline CMR & -1.3 \\
\hline ETH & -0.5 \\
\hline MWI & -0.4 \\
\hline GHA & -0.0 \\
\hline ZWE & 0.6 \\
\hline TZA & 1.4 \\
\hline MUS & 1.4 \\
\hline KEN & 2.0 \\
\hline UGA & 2.5 \\
\hline
\end{tabular}




\section{Appendix 2: Country Codes and Names}

\begin{tabular}{|c|c|c|c|c|c|}
\hline \multicolumn{2}{|c|}{ AFRICA } & \multirow{2}{*}{$\begin{array}{l}\text { CRI } \\
\text { DMA }\end{array}$} & \multirow{2}{*}{$\begin{array}{l}\text { Costa Rica } \\
\text { Dominica }\end{array}$} & \multirow{2}{*}{$\begin{array}{l}\text { KOR } \\
\text { KWT }\end{array}$} & \multirow{2}{*}{$\begin{array}{l}\text { Korea } \\
\text { Kuwait }\end{array}$} \\
\hline DZA & Algeria & & & & \\
\hline $\mathrm{BEN}$ & Benin & DOM & Dominican Republic & MYS & Malaysia \\
\hline BWA & Botswana & SLV & El Salvador & NPL & Nepal \\
\hline HVO & Burkina Faso & GTM & Guatemala & OMN & Oman \\
\hline BDI & Burundi & HTI & Haiti & PAK & Pakistan \\
\hline CMR & Cameroon & HND & Honduras & PHL & Philippines \\
\hline \multirow[t]{2}{*}{$\mathrm{CAF}$} & Central & $\mathrm{JAM}$ & Jamaica & SAU & Saudi Arabia \\
\hline & Republic & MEX & Mexico & SGP & Singapore \\
\hline TCD & Chad & NIC & Nicaragua & LKA & Sri Lanka \\
\hline COM & Comoros & PAN & Panama & SYR & Syria \\
\hline $\mathrm{COG}$ & Congo & LCA & St. Lucia & THA & Thailand \\
\hline ETH & Ethiopia & VCT & St. Vincent & YEM & South Yemen \\
\hline GHA & Ghana & TTO & Trinidad \& Tobago & & \\
\hline GIN & Guinea & USA & United States & \multicolumn{2}{|c|}{ EUROPE } \\
\hline CIV & Ivory Coast & & & AUT & Austria \\
\hline KEN & Kenya & \multicolumn{2}{|c|}{ SOUTH AMERICA } & BEL & Belgium \\
\hline LSO & Lesotho & ARG & Argentina & CYP & Cyprus \\
\hline LBR & Liberia & BOL & Bolivia & DNK & Denmark \\
\hline MDG & Madagascar & BRA & Brazil & FIN & Finland \\
\hline MWI & Malawi & CHL & Chile & FRA & France \\
\hline MLI & Mali & COL & Colombia & DEU & Germany \\
\hline MRT & Mauritania & ECU & Ecuador & GRC & Greece \\
\hline MUS & Mauritius & GUY & Guyana & HUN & Hungary \\
\hline MAR & Morocco & PRY & Paraguay & ISL & Iceland \\
\hline NER & Niger & PER & Peru & IRL & Ireland \\
\hline NGA & Nigeria & SUR & Suriname & ITA & Italy \\
\hline RWA & Rwanda & URY & Uruguay & LUX & Luxembourg \\
\hline SEN & Senegal & VEN & Venezuela & MLT & Malta \\
\hline SYC & Seychelles & & & NLD & Netherlands \\
\hline SLE & Sierra Leone & ASIA & & NOR & Norway \\
\hline SOM & Somalia & AFG & Afghanistan & POL & Poland \\
\hline SDN & Sudan & BHR & Bahrain & PRT & Portugal \\
\hline SWZ & Swaziland & BGD & Bangladesh & ESP & Spain \\
\hline TZA & Tanzania & BUR & Burma & SWE & Sweden \\
\hline TGO & Togo & $\mathrm{CHN}$ & China & $\mathrm{CHE}$ & Switzerland \\
\hline UGA & Uganda & $\mathrm{HKG}$ & Hong Kong & TUR & Turkey \\
\hline ZAR & Zaire & IND & India & YUG & Yugoslavia \\
\hline ZMB & Zambia & IDN & Indonesia & & \\
\hline \multirow{2}{*}{\multicolumn{2}{|c|}{ ZWE Zimbabwe }} & IRN & Iran & \multicolumn{2}{|c|}{ OCEANIA } \\
\hline & & IRQ & Iraq & FJI & Fiji \\
\hline \multicolumn{2}{|c|}{ LATIN AMERICA \& } & ISR & Israel & NZL & New Zealand \\
\hline \multirow{2}{*}{\multicolumn{2}{|c|}{$\begin{array}{l}\text { CARIBBEAN } \\
\text { BRB Barbados }\end{array}$}} & JPN & Japan & PNG & Papua New Guinea \\
\hline & & JOR & Jordan & & \\
\hline
\end{tabular}


Appendix 3: Human Capital Growth Rates (ZHK-Barro and ZHK-Nehru) and Human Capital (HKNehru and HK-Barro) to Physical Capital (K) and GDP (Y) Ratios

\begin{tabular}{|c|c|c|c|c|c|c|}
\hline Country & Period & $\begin{array}{c}\text { ZHK } \\
\text { (Barro) }\end{array}$ & $\begin{array}{c}\text { ZHK } \\
\text { (Nehru) }\end{array}$ & $\mathrm{K} / \mathrm{Y}$ & HKN/K & $\mathrm{HKB} / \mathrm{K}$ \\
\hline CMR & $\begin{array}{c}2 \\
3 \\
\text { Avg }\end{array}$ & $\begin{array}{l}-0.033 \\
-0.013 \\
-0.023\end{array}$ & $\begin{array}{l}0.106 \\
0.039 \\
0.073\end{array}$ & $\begin{array}{l}0.429 \\
0.725 \\
0.824\end{array}$ & $\begin{array}{l}5.370 \\
9.094 \\
7.232\end{array}$ & $\begin{array}{l}1.595 \\
3.741 \\
2.668\end{array}$ \\
\hline ETH & $\begin{array}{c}1 \\
2 \\
3 \\
4 \\
5 \\
6 \\
\text { Avg }\end{array}$ & $\begin{array}{l}\cdot \\
\cdot \\
. \\
.\end{array}$ & $\begin{array}{l}0.152 \\
0.099 \\
0.021 \\
0.126 \\
0.045 \\
0.089\end{array}$ & $\begin{array}{l}0.498 \\
0.681 \\
0.734 \\
0.727 \\
0.868 \\
1.122 \\
0.772\end{array}$ & $\begin{array}{r}16.372 \\
17.258 \\
15.140 \\
13.273 \\
9.896 \\
10.864 \\
13.800\end{array}$ & \\
\hline GHA & $\begin{array}{c}1 \\
2 \\
3 \\
4 \\
5 \\
6 \\
\text { Avg }\end{array}$ & $\begin{array}{r}0.111 \\
-0.009 \\
-0.132 \\
0.121 \\
. \\
0.023\end{array}$ & $\begin{array}{r}0.147 \\
0.021 \\
-0.093 \\
0.096 \\
0.111 \\
0.056\end{array}$ & $\begin{array}{l}1.114 \\
1.460 \\
1.359 \\
1.546 \\
1.570 \\
1.372 \\
1.404\end{array}$ & $\begin{array}{r}10.221 \\
9.738 \\
6.184 \\
12.243 \\
10.809 \\
6.838 \\
9.339\end{array}$ & $\begin{array}{r}5.629 \\
5.838 \\
5.067 \\
10.427 \\
9.480 \\
7.288\end{array}$ \\
\hline $\mathrm{KEN}$ & $\begin{array}{c}2 \\
3 \\
4 \\
5 \\
6 \\
\text { Avg }\end{array}$ & $\begin{array}{r}0.058 \\
0.077 \\
0.152 \\
-0.034 \\
. \\
0.063\end{array}$ & $\begin{array}{l}0.094 \\
0.145 \\
0.066 \\
0.035 \\
0.161 \\
0.100\end{array}$ & $\begin{array}{l}2.693 \\
3.093 \\
2.921 \\
2.748 \\
2.348 \\
2.761\end{array}$ & $\begin{array}{r}13.260 \\
12.443 \\
10.822 \\
9.258 \\
6.343 \\
10.425\end{array}$ & $\begin{array}{r}6.606 \\
8.400 \\
5.978 \\
5.533 \\
. \\
6.629\end{array}$ \\
\hline MWI & $\begin{array}{c}1 \\
2 \\
3 \\
4 \\
5 \\
6 \\
\text { Avg }\end{array}$ & $\begin{array}{r}0.059 \\
0.082 \\
-0.015 \\
0.013 \\
. \\
0.035\end{array}$ & $\begin{array}{r}0.092 \\
-0.063 \\
0.024 \\
0.025 \\
0.047 \\
0.025\end{array}$ & $\begin{array}{l}0.889 \\
1.398 \\
1.993 \\
2.367 \\
2.600 \\
2.192 \\
1.907\end{array}$ & $\begin{array}{r}2.468 \\
3.809 \\
7.713 \\
11.309 \\
12.928 \\
9.180 \\
7.901\end{array}$ & $\begin{array}{r}3.004 \\
5.004 \\
6.829 \\
8.700 \\
11.241 \\
6.956\end{array}$ \\
\hline
\end{tabular}




\begin{tabular}{|c|c|c|c|c|c|c|}
\hline Country & Period & $\begin{array}{c}\text { ZHK } \\
\text { (Barro) }\end{array}$ & $\begin{array}{c}\text { ZHK } \\
\text { (Nehru) }\end{array}$ & $\mathrm{K} / \mathrm{Y}$ & $\mathrm{HKN} / \mathrm{K}$ & $\mathrm{HKB} / \mathrm{K}$ \\
\hline MUS & $\begin{array}{c}1 \\
2 \\
3 \\
4 \\
5 \\
6 \\
\text { Avg }\end{array}$ & $\begin{array}{r}-0.021 \\
0.198 \\
0.179 \\
-0.022 \\
0.083\end{array}$ & $\begin{array}{l}0.006 \\
0.173 \\
0.129 \\
0.009 \\
0.085 \\
0.080\end{array}$ & $\begin{array}{l}1.852 \\
2.102 \\
2.056 \\
2.147 \\
2.195 \\
1.913 \\
2.044\end{array}$ & $\begin{array}{r}11.164 \\
12.571 \\
10.142 \\
6.229 \\
5.969 \\
6.193 \\
8.711\end{array}$ & $\begin{array}{r}9.931 \\
12.193 \\
9.601 \\
5.013 \\
4.591 \\
\\
8.266\end{array}$ \\
\hline MAR & $\begin{array}{c}1 \\
2 \\
3 \\
4 \\
5 \\
6 \\
\text { Avg }\end{array}$ & & $\begin{array}{r}0.126 \\
0.113 \\
0.114 \\
0.094 \\
. \\
0.112\end{array}$ & $\begin{array}{l}0.825 \\
1.064 \\
1.299 \\
1.738 \\
2.039 \\
2.025 \\
1.499\end{array}$ & $\begin{array}{r}14.686 \\
15.808 \\
13.174 \\
14.545 \\
13.756 \\
. \\
14.394\end{array}$ & \\
\hline NGA & $\begin{array}{c}3 \\
4 \\
5 \\
6 \\
\text { Avg }\end{array}$ & & $\begin{array}{r}0.022 \\
0.078 \\
-0.057 \\
0.014\end{array}$ & $\begin{array}{l}1.631 \\
2.918 \\
4.034 \\
3.182 \\
2.941\end{array}$ & $\begin{array}{r}27.336 \\
36.953 \\
46.290 \\
36.860\end{array}$ & \\
\hline SLE & $\begin{array}{c}3 \\
4 \\
\text { Avg }\end{array}$ & $\begin{array}{l}0.043 \\
0.025 \\
0.038\end{array}$ & $\begin{array}{l}0.026 \\
0.099 \\
0.053\end{array}$ & $\begin{array}{l}1.231 \\
1.331 \\
1.333\end{array}$ & $\begin{array}{r}11.124 \\
8.901 \\
10.013\end{array}$ & $\begin{array}{l}4.511 \\
3.955 \\
4.233\end{array}$ \\
\hline TZA & $\begin{array}{c}2 \\
3 \\
4 \\
5 \\
6 \\
\text { Avg }\end{array}$ & $\begin{array}{r}0.020 \\
-0.011 \\
0.021 \\
0.033 \\
0.016\end{array}$ & $\begin{array}{r}0.157 \\
0.081 \\
0.100 \\
0.089 \\
-0.028 \\
0.080\end{array}$ & $\begin{array}{l}1.610 \\
1.949 \\
2.189 \\
2.479 \\
2.306 \\
1.994\end{array}$ & $\begin{array}{r}11.234 \\
10.830 \\
11.812 \\
9.427 \\
8.816 \\
10.638\end{array}$ & $\begin{array}{r}1.719 \\
2.743 \\
4.394 \\
4.711 \\
. \\
2.954\end{array}$ \\
\hline UGA & $\begin{array}{c}2 \\
3 \\
4 \\
5 \\
\text { Avg }\end{array}$ & $\begin{array}{r}-0.054 \\
-0.004 \\
-0.082 \\
-0.004 \\
0.035\end{array}$ & $\begin{array}{r}0.025 \\
-0.055 \\
-0.092 \\
0.049 \\
-0.012\end{array}$ & $\begin{array}{l}1.450 \\
1.824 \\
1.966 \\
1.872 \\
1.731\end{array}$ & $\begin{array}{r}4.981 \\
8.383 \\
10.866 \\
17.276 \\
10.377\end{array}$ & $\begin{array}{r}4.246 \\
7.167 \\
8.187 \\
14.821 \\
8.605\end{array}$ \\
\hline ZAR & $\begin{array}{c}3 \\
4 \\
5 \\
6 \\
\text { Avg }\end{array}$ & $\begin{array}{r}0.041 \\
-0.030 \\
0.005\end{array}$ & $\begin{array}{r}0.040 \\
-0.012 \\
-0.112 \\
-0.028\end{array}$ & $\begin{array}{l}0.413 \\
0.611 \\
1.079 \\
1.270 \\
0.739\end{array}$ & $\begin{array}{r}3.403 \\
3.215 \\
7.307 \\
10.934 \\
6.214\end{array}$ & $\begin{array}{r}3.354 \\
3.185 \\
7.677 \\
4.738\end{array}$ \\
\hline
\end{tabular}




\begin{tabular}{|c|c|c|c|c|c|c|}
\hline Country & Period & $\begin{array}{c}\text { ZHK } \\
\text { (Barro) }\end{array}$ & $\begin{array}{c}\text { ZHK } \\
\text { (Nehru) }\end{array}$ & $\mathrm{K} / \mathrm{Y}$ & $\mathrm{HKN} / \mathrm{K}$ & $\mathrm{HKB} / \mathrm{K}$ \\
\hline ZMB & $\begin{array}{c}2 \\
3 \\
4 \\
5 \\
\text { Avg }\end{array}$ & $\begin{array}{l}0.018 \\
0.009 \\
0.079 \\
0.035\end{array}$ & $\begin{array}{r}. \\
0.141 \\
-0.012 \\
0.085 \\
0.072\end{array}$ & $\begin{array}{l}3.249 \\
4.308 \\
4.590 \\
3.960 \\
3.630\end{array}$ & $\begin{array}{l}35.282 \\
37.024 \\
26.904 \\
16.214 \\
28.856\end{array}$ & $\begin{array}{r}11.270 \\
16.670 \\
14.106 \\
8.027 \\
12.518\end{array}$ \\
\hline ZWE & $\begin{array}{c}3 \\
4 \\
5 \\
6 \\
\text { Avg }\end{array}$ & $\begin{array}{r}0.090 \\
0.238 \\
-0.035 \\
. \\
0.098 \\
\end{array}$ & $\begin{array}{r}0.097 \\
0.241 \\
-0.019 \\
-0.031 \\
0.072 \\
\end{array}$ & $\begin{array}{l}2.045 \\
2.636 \\
2.358 \\
2.346 \\
2.346 \\
\end{array}$ & $\begin{array}{l}9.061 \\
6.404 \\
5.810 \\
5.925 \\
6.800 \\
\end{array}$ & $\begin{array}{r}7.549 \\
5.431 \\
5.195 \\
6.058 \\
\end{array}$ \\
\hline CRI & $\begin{array}{c}1 \\
2 \\
3 \\
4 \\
5 \\
6 \\
\text { Avg }\end{array}$ & $\begin{array}{r}0.049 \\
0.052 \\
0.123 \\
0.085 \\
0.002 \\
\text {. } \\
0.062\end{array}$ & $\begin{array}{l}0.054 \\
0.072 \\
0.109 \\
0.096 \\
0.008 \\
0.062 \\
0.067\end{array}$ & $\begin{array}{l}1.073 \\
1.153 \\
1.285 \\
1.545 \\
1.853 \\
1.810 \\
1.453\end{array}$ & $\begin{array}{l}4.361 \\
4.745 \\
4.510 \\
4.527 \\
5.450 \\
4.449 \\
4.674\end{array}$ & $\begin{array}{r}3.420 \\
3.991 \\
3.765 \\
3.816 \\
4.813 \\
\\
3.961\end{array}$ \\
\hline DOM & $\begin{array}{c}2 \\
3 \\
4 \\
5 \\
\text { Avg } \\
\end{array}$ & $\begin{array}{r}-0.036 \\
0.044 \\
0.085 \\
0.031\end{array}$ & $\begin{array}{l}\dot{ } \\
\dot{ } \\
\dot{ } \\
\dot{ }\end{array}$ & $\begin{array}{l}1.014 \\
1.215 \\
1.572 \\
1.787 \\
1.405\end{array}$ & $\begin{array}{l}. \\
. \\
. \\
.\end{array}$ & $\begin{array}{r}7.583 \\
14.417 \\
23.810 \\
20.213 \\
16.506\end{array}$ \\
\hline SLV & $\begin{array}{c}1 \\
2 \\
3 \\
4 \\
5 \\
\text { Avg }\end{array}$ & $\begin{array}{l}0.047 \\
0.066 \\
0.042 \\
0.122 \\
0.104 \\
0.076\end{array}$ & $\begin{array}{l}0.047 \\
0.060 \\
0.052 \\
0.115 \\
0.109 \\
0.077\end{array}$ & $\begin{array}{l}0.793 \\
0.945 \\
1.040 \\
1.300 \\
1.711 \\
1.242\end{array}$ & $\begin{array}{l}5.951 \\
7.101 \\
7.481 \\
7.685 \\
6.226 \\
6.889\end{array}$ & $\begin{array}{l}5.241 \\
6.142 \\
6.661 \\
6.911 \\
5.483 \\
6.088\end{array}$ \\
\hline GTM & $\begin{array}{c}1 \\
2 \\
3 \\
4 \\
5 \\
\text { Avg }\end{array}$ & $\begin{array}{l}0.039 \\
0.048 \\
0.043 \\
0.008 \\
0.023 \\
0.032\end{array}$ & $\begin{array}{l}0.035 \\
0.045 \\
0.022 \\
0.002 \\
0.026 \\
0.026\end{array}$ & $\begin{array}{l}1.115 \\
1.263 \\
1.304 \\
1.435 \\
1.670 \\
1.398\end{array}$ & $\begin{array}{l}11.596 \\
13.804 \\
15.732 \\
21.880 \\
25.120 \\
17.626\end{array}$ & $\begin{array}{l}12.376 \\
14.541 \\
15.531 \\
20.469 \\
23.338 \\
17.251\end{array}$ \\
\hline
\end{tabular}




\begin{tabular}{|c|c|c|c|c|c|c|}
\hline Country & Period & $\begin{array}{c}\text { ZHK } \\
\text { (Barro) }\end{array}$ & $\begin{array}{c}\text { ZHK } \\
\text { (Nehru) }\end{array}$ & $\mathrm{K} / \mathrm{Y}$ & HKN/K & $\mathrm{HKB} / \mathrm{K}$ \\
\hline HTI & $\begin{array}{c}2 \\
3 \\
4 \\
5 \\
6 \\
\text { Avg }\end{array}$ & $\begin{array}{r}0.006 \\
-0.050 \\
0.086 \\
-0.049 \\
.0 .002 \\
\end{array}$ & $\begin{array}{r}0.009 \\
-0.067 \\
0.061 \\
-0.036 \\
0.395 \\
0.073 \\
\end{array}$ & $\begin{array}{l}0.323 \\
0.549 \\
0.893 \\
1.341 \\
1.558 \\
0.933\end{array}$ & $\begin{array}{r}2.679 \\
5.757 \\
12.787 \\
18.885 \\
13.172 \\
10.656 \\
\end{array}$ & $\begin{array}{r}2.715 \\
5.693 \\
11.101 \\
17.571 \\
9.270 \\
\end{array}$ \\
\hline HND & $\begin{array}{c}1 \\
2 \\
3 \\
4 \\
5 \\
6 \\
\text { Avg }\end{array}$ & $\begin{array}{r}0.069 \\
0.024 \\
0.041 \\
0.088 \\
0.100 \\
. \\
0.064\end{array}$ & $\begin{array}{l}0.108 \\
0.045 \\
0.052 \\
0.079 \\
0.068 \\
0.017 \\
0.061\end{array}$ & $\begin{array}{l}0.910 \\
1.085 \\
1.254 \\
1.387 \\
1.578 \\
1.520 \\
1.289\end{array}$ & $\begin{array}{l}7.046 \\
7.960 \\
8.903 \\
9.535 \\
8.620 \\
7.800 \\
8.311\end{array}$ & $\begin{array}{r}5.917 \\
7.462 \\
9.007 \\
9.666 \\
7.786 \\
7.968\end{array}$ \\
\hline JAM & $\begin{array}{c}1 \\
2 \\
3 \\
4 \\
5 \\
\text { Avg }\end{array}$ & $\begin{array}{l}0.079 \\
0.023 \\
0.164 \\
0.083 \\
0.031 \\
0.076\end{array}$ & $\begin{array}{r}0.080 \\
0.000 \\
0.140 \\
0.093 \\
-0.010 \\
0.061\end{array}$ & $\begin{array}{l}2.340 \\
2.779 \\
3.192 \\
3.829 \\
3.643 \\
3.186\end{array}$ & $\begin{array}{r}9.950 \\
14.124 \\
12.992 \\
9.122 \\
7.266 \\
10.691\end{array}$ & $\begin{array}{r}14.448 \\
19.269 \\
16.456 \\
10.818 \\
8.177 \\
13.833\end{array}$ \\
\hline MEX & $\begin{array}{c}1 \\
2 \\
3 \\
4 \\
5 \\
6 \\
\text { Avg }\end{array}$ & $\begin{array}{r}0.043 \\
0.137 \\
0.021 \\
0.016 \\
. \\
0.054\end{array}$ & $\begin{array}{r}.0 .005 \\
0.153 \\
0.062 \\
0.015 \\
-0.178 \\
0.009\end{array}$ & $\begin{array}{l}0.804 \\
0.929 \\
1.084 \\
1.214 \\
1.391 \\
1.577 \\
1.167\end{array}$ & $\begin{array}{r}8.688 \\
13.983 \\
14.757 \\
10.517 \\
14.277 \\
18.552 \\
13.463\end{array}$ & $\begin{array}{r}7.879 \\
10.959 \\
11.399 \\
9.435 \\
13.391 \\
. \\
10.612\end{array}$ \\
\hline NIC & $\begin{array}{c}1 \\
2 \\
3 \\
4 \\
5 \\
\text { Avg }\end{array}$ & $\begin{array}{l}0.009 \\
0.023 \\
0.022 \\
0.263 \\
0.079\end{array}$ & $\begin{array}{l}. \\
. \\
. \\
. \\
. \\
\text {. }\end{array}$ & $\begin{array}{l}3.097 \\
3.978 \\
4.346 \\
5.368 \\
6.783 \\
5.340\end{array}$ & $\begin{array}{l}. \\
. \\
. \\
. \\
. \\
\text {. }\end{array}$ & $\begin{array}{l}26.873 \\
42.621 \\
48.681 \\
58.287 \\
33.776 \\
42.047\end{array}$ \\
\hline PAN & $\begin{array}{c}1 \\
2 \\
3 \\
4 \\
5 \\
6 \\
\text { Avg }\end{array}$ & $\begin{array}{r}0.049 \\
0.100 \\
0.030 \\
0.084 \\
0.083 \\
. \\
0.069\end{array}$ & $\begin{array}{l}0.066 \\
0.116 \\
0.040 \\
0.099 \\
0.085 \\
0.019 \\
0.071\end{array}$ & $\begin{array}{l}1.041 \\
1.275 \\
1.739 \\
1.992 \\
1.907 \\
2.007 \\
1.660\end{array}$ & $\begin{array}{l}4.701 \\
5.459 \\
7.809 \\
7.336 \\
6.108 \\
5.293 \\
6.118\end{array}$ & $\begin{array}{l}3.320 \\
4.169 \\
6.253 \\
6.364 \\
5.376\end{array}$ \\
\hline
\end{tabular}




\begin{tabular}{|c|c|c|c|c|c|c|}
\hline Country & Period & $\begin{array}{c}\text { ZHK } \\
\text { (Barro) }\end{array}$ & $\begin{array}{c}\text { ZHK } \\
\text { (Nehru) }\end{array}$ & $\mathrm{K} / \mathrm{Y}$ & HKN/K & $\mathrm{HKB} / \mathrm{K}$ \\
\hline TTO & $\begin{array}{c}2 \\
3 \\
4 \\
5 \\
\text { Avg }\end{array}$ & $\begin{array}{l}0.047 \\
0.092 \\
0.148 \\
0.088 \\
0.094\end{array}$ & $\begin{array}{l}. \\
. \\
. \\
.\end{array}$ & $\begin{array}{l}1.032 \\
1.200 \\
1.501 \\
1.974 \\
1.690\end{array}$ & $\begin{array}{l}\cdot \\
. \\
. \\
.\end{array}$ & $\begin{array}{l}5.096 \\
5.198 \\
5.232 \\
3.646 \\
4.793\end{array}$ \\
\hline USA & $\begin{array}{c}1 \\
2 \\
3 \\
4 \\
5 \\
6 \\
\text { Avg }\end{array}$ & $\begin{array}{r}0.105 \\
0.042 \\
0.108 \\
0.059 \\
. \\
0.079\end{array}$ & $\begin{array}{l}\text { 0.094 } \\
0.051 \\
0.091 \\
0.068 \\
0.073 \\
0.076\end{array}$ & $\begin{array}{l}1.238 \\
1.386 \\
1.546 \\
1.602 \\
1.683 \\
1.692 \\
1.525\end{array}$ & $\begin{array}{l}2.061 \\
2.030 \\
1.925 \\
1.530 \\
1.312 \\
1.209 \\
1.678\end{array}$ & $\begin{array}{r}1.895 \\
1.806 \\
1.773 \\
1.324 \\
1.140 \\
. \\
1.587\end{array}$ \\
\hline $\mathrm{ARG}$ & $\begin{array}{c}1 \\
2 \\
3 \\
4 \\
5 \\
6 \\
\text { Avg }\end{array}$ & $\begin{array}{r}-0.027 \\
-0.004 \\
0.122 \\
-0.218 \\
-0.032\end{array}$ & $\begin{array}{r}-0.031 \\
0.005 \\
0.143 \\
-0.250 \\
0.069 \\
-0.012\end{array}$ & $\begin{array}{l}1.254 \\
1.456 \\
1.736 \\
2.011 \\
2.301 \\
2.095 \\
1.800\end{array}$ & $\begin{array}{r}4.578 \\
7.175 \\
10.416 \\
9.411 \\
10.930 \\
29.414 \\
11.980\end{array}$ & $\begin{array}{r}3.542 \\
5.490 \\
7.977 \\
7.922 \\
9.074 \\
6.801\end{array}$ \\
\hline BOL & $\begin{array}{c}1 \\
2 \\
3 \\
4 \\
5 \\
6 \\
\text { Avg }\end{array}$ & $\begin{array}{r}-0.010 \\
0.016 \\
0.080 \\
-0.145 \\
-0.015\end{array}$ & $\begin{array}{r}0.065 \\
0.072 \\
0.093 \\
-0.112 \\
0.029\end{array}$ & $\begin{array}{l}1.780 \\
1.989 \\
2.146 \\
2.409 \\
2.629 \\
2.257 \\
2.202\end{array}$ & $\begin{array}{r}10.029 \\
12.242 \\
12.101 \\
10.599 \\
13.133 \\
\text {. } \\
11.621\end{array}$ & $\begin{array}{r}4.883 \\
7.382 \\
9.776 \\
10.242 \\
13.566 \\
9.170\end{array}$ \\
\hline $\mathrm{CHL}$ & $\begin{array}{c}1 \\
2 \\
3 \\
4 \\
5 \\
\text { Avg }\end{array}$ & $\begin{array}{r}0.004 \\
-0.040 \\
0.042 \\
0.205 \\
0.245 \\
0.091\end{array}$ & $\begin{array}{r}0.021 \\
-0.034 \\
0.052 \\
0.208 \\
0.311 \\
0.112\end{array}$ & $\begin{array}{l}1.378 \\
1.535 \\
1.743 \\
1.699 \\
1.730 \\
1.611\end{array}$ & $\begin{array}{r}7.630 \\
11.149 \\
13.877 \\
7.359 \\
3.850 \\
8.773\end{array}$ & $\begin{array}{r}5.205 \\
8.000 \\
10.450 \\
5.725 \\
3.136 \\
6.503\end{array}$ \\
\hline $\mathrm{COL}$ & $\begin{array}{c}2 \\
3 \\
4 \\
5 \\
6 \\
\text { Avg }\end{array}$ & $\begin{array}{r}0.029 \\
0.057 \\
0.049 \\
0.148 \\
. \\
0.071\end{array}$ & $\begin{array}{l}0.033 \\
0.045 \\
0.071 \\
0.166 \\
0.028 \\
0.069\end{array}$ & $\begin{array}{l}1.365 \\
1.458 \\
1.494 \\
1.672 \\
1.685 \\
1.535\end{array}$ & $\begin{array}{l}18.067 \\
20.976 \\
21.515 \\
11.817 \\
11.966 \\
16.868\end{array}$ & $\begin{array}{r}11.881 \\
13.411 \\
14.556 \\
8.774 \\
.155\end{array}$ \\
\hline
\end{tabular}




\begin{tabular}{|c|c|c|c|c|c|c|}
\hline Country & Period & $\begin{array}{c}\text { ZHK } \\
\text { (Barro) }\end{array}$ & $\begin{array}{c}\text { ZHK } \\
\text { (Nehru) }\end{array}$ & $\mathrm{K} / \mathrm{Y}$ & $\mathrm{HKN} / \mathrm{K}$ & $\mathrm{HKB} / \mathrm{K}$ \\
\hline \multirow[t]{7}{*}{ ECU } & 1 & 0.074 & 0.101 & 1.982 & 17.444 & 11.823 \\
\hline & 2 & 0.075 & 0.070 & 2.405 & 18.932 & 13.219 \\
\hline & 3 & 0.090 & 0.109 & 2.158 & 15.606 & 11.267 \\
\hline & 4 & 0.040 & 0.029 & 2.257 & 18.058 & 13.105 \\
\hline & 5 & 0.088 & 0.092 & 2.566 & 16.795 & 12.341 \\
\hline & 6 & & -0.009 & 2.546 & 15.110 & \\
\hline & Avg & 0.074 & 0.065 & 2.319 & 16.991 & 12.351 \\
\hline \multirow[t]{6}{*}{ PRY } & 1 & 0.024 & 0.044 & 0.774 & 5.615 & 4.884 \\
\hline & 2 & 0.052 & 0.047 & 0.946 & 6.809 & 6.024 \\
\hline & 3 & -0.013 & -0.021 & 1.106 & 10.736 & 9.234 \\
\hline & 4 & 0.129 & 0.109 & 1.401 & 15.671 & 12.452 \\
\hline & 5 & -0.004 & -0.005 & 1.998 & 23.318 & 18.184 \\
\hline & Avg & 0.038 & 0.035 & 1.401 & 12.430 & 10.155 \\
\hline \multirow[t]{7}{*}{ PER } & 1 & & & 1.608 & 9.505 & 7.325 \\
\hline & 2 & -0.038 & -0.036 & 1.797 & 15.137 & 11.686 \\
\hline & 3 & 0.049 & 0.068 & 1.729 & 16.017 & 12.995 \\
\hline & 4 & 0.051 & 0.045 & 1.943 & 17.041 & 13.896 \\
\hline & 5 & -0.050 & -0.046 & 2.270 & 19.423 & 15.866 \\
\hline & 6 & & 0.211 & 2.318 & 19.090 & \\
\hline & Avg & 0.003 & 0.048 & 1.944 & 16.035 & 12.353 \\
\hline \multirow[t]{7}{*}{ URY } & 1 & & & 1.361 & 4.452 & 3.692 \\
\hline & 2 & -0.006 & 0.009 & 1.452 & 4.905 & 4.258 \\
\hline & 3 & 0.013 & 0.009 & 1.532 & 5.512 & 4.832 \\
\hline & 4 & 0.030 & 0.046 & 1.716 & 6.259 & 5.728 \\
\hline & 5 & -0.092 & -0.055 & 2.214 & 8.150 & 8.624 \\
\hline & 6 & & 0.133 & 1.848 & 6.335 & \\
\hline & Avg & -0.014 & 0.028 & 1.687 & 5.935 & 5.427 \\
\hline \multirow[t]{6}{*}{ VEN } & 1 & & & 1.878 & 15.181 & 11.241 \\
\hline & 2 & 0.082 & 0.112 & 1.832 & 13.675 & 10.915 \\
\hline & 3 & 0.090 & 0.085 & 1.938 & 13.045 & 10.873 \\
\hline & 4 & 0.074 & 0.065 & 2.369 & 15.787 & 12.674 \\
\hline & 5 & 0.300 & 0.383 & 2.953 & 9.927 & 8.933 \\
\hline & Avg & 0.137 & 0.161 & 2.289 & 13.523 & 10.927 \\
\hline \multirow[t]{4}{*}{ BGD } & 3 & 0.136 & 0.099 & 1.169 & 28.266 & 59.247 \\
\hline & 4 & 0.264 & 0.172 & 1.064 & 13.171 & 21.276 \\
\hline & 5 & 0.201 & 0.154 & 1.208 & 12.260 & 15.438 \\
\hline & Avg & 0.200 & 0.142 & 1.159 & 17.899 & 31.987 \\
\hline
\end{tabular}




\begin{tabular}{|c|c|c|c|c|c|c|}
\hline Country & Period & $\begin{array}{c}\text { ZHK } \\
\text { (Barro) }\end{array}$ & $\begin{array}{c}\text { ZHK } \\
\text { (Nehru) }\end{array}$ & $\mathrm{K} / \mathrm{Y}$ & $\mathrm{HKN} / \mathrm{K}$ & $\mathrm{HKB} / \mathrm{K}$ \\
\hline BUR & $\begin{array}{c}2 \\
3 \\
\text { Avg }\end{array}$ & $\begin{array}{l}-0.020 \\
-0.053 \\
-0.037 \\
\end{array}$ & $\begin{array}{l}0.016 \\
0.015 \\
0.015\end{array}$ & $\begin{array}{l}1.146 \\
1.193 \\
1.246 \\
\end{array}$ & $\begin{array}{l}10.189 \\
10.817 \\
10.503 \\
\end{array}$ & $\begin{array}{l}7.661 \\
9.352 \\
8.507\end{array}$ \\
\hline $\mathrm{CHN}$ & $\begin{array}{c}4 \\
5 \\
6 \\
\text { Avg }\end{array}$ & . & $\begin{array}{r}0.177 \\
0.115 \\
0.146\end{array}$ & $\begin{array}{l}1.650 \\
1.653 \\
1.820 \\
1.550\end{array}$ & $\begin{array}{r}12.398 \\
9.672 \\
10.024 \\
10.698\end{array}$ & \\
\hline IND & $\begin{array}{c}1 \\
2 \\
3 \\
4 \\
5 \\
6 \\
\text { Avg }\end{array}$ & $\begin{array}{r}0.007 \\
0.070 \\
0.088 \\
0.016 \\
0.114 \\
. \\
0.059 \\
\end{array}$ & $\begin{array}{l}0.005 \\
0.082 \\
0.044 \\
0.036 \\
0.096 \\
0.102 \\
0.061 \\
\end{array}$ & $\begin{array}{l}1.205 \\
1.541 \\
1.710 \\
1.791 \\
1.826 \\
1.770 \\
1.641 \\
\end{array}$ & $\begin{array}{r}12.528 \\
14.647 \\
14.159 \\
12.612 \\
10.548 \\
9.262 \\
12.293 \\
\end{array}$ & $\begin{array}{r}11.338 \\
13.785 \\
12.276 \\
10.943 \\
8.692 \\
\text { } \\
11.407 \\
\end{array}$ \\
\hline IDN & $\begin{array}{c}3 \\
4 \\
5 \\
6 \\
\text { Avg } \\
\end{array}$ & $\begin{array}{r}-0.012 \\
-0.104 \\
0.001 \\
. \\
-0.038 \\
\end{array}$ & $\begin{array}{r}-0.141 \\
-0.025 \\
0.035 \\
0.012 \\
-0.030 \\
\end{array}$ & $\begin{array}{l}0.823 \\
1.094 \\
1.510 \\
1.831 \\
1.110 \\
\end{array}$ & $\begin{array}{l}12.756 \\
39.337 \\
70.055 \\
87.529 \\
52.419 \\
\end{array}$ & $\begin{array}{r}6.064 \\
17.218 \\
40.907 \\
\\
21.396 \\
\end{array}$ \\
\hline IRN & $\begin{array}{c}1 \\
2 \\
3 \\
4 \\
\text { Avg } \\
\end{array}$ & $\begin{array}{r}-0.000 \\
0.291 \\
0.093 \\
0.128 \\
\end{array}$ & $\begin{array}{r}\text {. } \\
0.044 \\
0.251 \\
0.107 \\
0.134 \\
\end{array}$ & $\begin{array}{l}0.595 \\
0.748 \\
0.793 \\
1.383 \\
1.269 \\
\end{array}$ & $\begin{array}{r}7.856 \\
12.012 \\
9.793 \\
8.961 \\
9.656 \\
\end{array}$ & $\begin{array}{r}6.861 \\
11.889 \\
9.422 \\
8.495 \\
9.167 \\
\end{array}$ \\
\hline ISR & $\begin{array}{c}2 \\
3 \\
4 \\
5 \\
6 \\
\text { Avg } \\
\end{array}$ & $\begin{array}{r}0.118 \\
0.106 \\
0.110 \\
-0.024 \\
. \\
0.077 \\
\end{array}$ & $\begin{array}{r}0.166 \\
0.162 \\
0.119 \\
0.007 \\
-0.098 \\
0.071 \\
\end{array}$ & $\begin{array}{l}2.461 \\
2.407 \\
2.418 \\
2.251 \\
2.111 \\
2.329\end{array}$ & $\begin{array}{r}12.800 \\
8.511 \\
5.692 \\
4.541 \\
5.595 \\
7.428\end{array}$ & $\begin{array}{r}4.201 \\
3.579 \\
2.624 \\
2.331 \\
3.183\end{array}$ \\
\hline JPN & $\begin{array}{c}1 \\
2 \\
3 \\
4 \\
5 \\
6 \\
\text { Avg }\end{array}$ & $\begin{array}{r}0.124 \\
0.105 \\
0.125 \\
0.044 \\
0.066 \\
\text {. } \\
0.093 \\
\end{array}$ & $\begin{array}{l}0.127 \\
0.119 \\
0.116 \\
0.030 \\
0.056 \\
0.061 \\
0.085 \\
\end{array}$ & $\begin{array}{l}1.077 \\
1.387 \\
1.885 \\
2.269 \\
2.437 \\
2.505 \\
1.927 \\
\end{array}$ & $\begin{array}{l}1.742 \\
2.096 \\
2.300 \\
2.609 \\
2.738 \\
2.660 \\
2.357 \\
\end{array}$ & $\begin{array}{l}2.026 \\
2.554 \\
2.797 \\
3.006 \\
2.978\end{array}$ \\
\hline
\end{tabular}




\begin{tabular}{|c|c|c|c|c|c|c|}
\hline Country & Period & $\begin{array}{c}\mathrm{ZHK} \\
\text { (Barro) }\end{array}$ & $\begin{array}{c}\text { ZHK } \\
\text { (Nehru) }\end{array}$ & $\mathrm{K} / \mathrm{Y}$ & HKN/K & $\mathrm{HKB} / \mathrm{K}$ \\
\hline KOR & $\begin{array}{c}1 \\
2 \\
3 \\
4 \\
5 \\
6 \\
\text { Avg }\end{array}$ & $\begin{array}{r}0.145 \\
0.026 \\
0.216 \\
0.132 \\
. \\
0.130\end{array}$ & $\begin{array}{l}0.155 \\
0.036 \\
0.223 \\
0.160 \\
0.126 \\
0.140\end{array}$ & $\begin{array}{l}0.490 \\
0.764 \\
1.054 \\
1.400 \\
1.761 \\
1.812 \\
1.214\end{array}$ & $\begin{array}{l}3.159 \\
4.796 \\
7.598 \\
5.846 \\
5.150 \\
4.724 \\
5.212\end{array}$ & $\begin{array}{r}2.263 \\
3.520 \\
5.834 \\
4.728 \\
4.524 \\
4.174\end{array}$ \\
\hline MYS & $\begin{array}{c}2 \\
3 \\
4 \\
5 \\
6 \\
\text { Avg }\end{array}$ & $\begin{array}{r}0.095 \\
0.121 \\
0.109 \\
\text {. } \\
0.108\end{array}$ & $\begin{array}{l}. \\
0.129 \\
0.157 \\
0.124 \\
0.039 \\
0.112\end{array}$ & $\begin{array}{l}0.960 \\
1.346 \\
1.596 \\
2.078 \\
2.267 \\
1.649\end{array}$ & $\begin{array}{l}6.404 \\
5.970 \\
5.381 \\
4.633 \\
5.597\end{array}$ & $\begin{array}{r}4.442 \\
4.882 \\
4.797 \\
4.707\end{array}$ \\
\hline PAK & $\begin{array}{c}1 \\
2 \\
3 \\
4 \\
5 \\
6 \\
\text { Avg }\end{array}$ & $\begin{array}{r}0.222 \\
0.091 \\
0.091 \\
-0.003 \\
0.084 \\
. \\
0.097\end{array}$ & $\begin{array}{l}0.120 \\
0.020 \\
0.134 \\
0.055 \\
0.090 \\
0.204 \\
0.104\end{array}$ & $\begin{array}{l}0.850 \\
1.352 \\
1.594 \\
1.558 \\
1.455 \\
1.417 \\
1.371\end{array}$ & $\begin{array}{l}15.188 \\
23.995 \\
19.831 \\
15.727 \\
15.790 \\
11.370 \\
16.984\end{array}$ & $\begin{array}{r}16.989 \\
18.865 \\
15.528 \\
16.249 \\
18.428 \\
17.212\end{array}$ \\
\hline PHL & $\begin{array}{c}2 \\
3 \\
4 \\
5 \\
6 \\
\text { Avg }\end{array}$ & $\begin{array}{r}-0.022 \\
0.065 \\
-0.034 \\
. \\
0.003\end{array}$ & $\begin{array}{r}-0.035 \\
0.055 \\
-0.019 \\
0.325 \\
0.081\end{array}$ & $\begin{array}{l}1.292 \\
1.351 \\
1.523 \\
2.011 \\
2.161 \\
1.567\end{array}$ & $\begin{array}{r}5.410 \\
8.046 \\
11.457 \\
14.255 \\
13.419 \\
10.517\end{array}$ & $\begin{array}{r}5.828 \\
8.336 \\
11.364 \\
14.468 \\
9.999\end{array}$ \\
\hline SGP & $\begin{array}{c}1 \\
2 \\
3 \\
4 \\
5 \\
\text { Avg }\end{array}$ & $\begin{array}{l}0.151 \\
0.107 \\
0.101 \\
0.291 \\
0.162\end{array}$ & $\begin{array}{l}0.167 \\
0.123 \\
0.181 \\
0.293 \\
0.191\end{array}$ & $\begin{array}{l}0.459 \\
1.067 \\
1.721 \\
2.189 \\
2.674 \\
1.838\end{array}$ & $\begin{array}{r}3.939 \\
8.286 \\
11.297 \\
10.248 \\
8.759 \\
8.506\end{array}$ & $\begin{array}{r}2.998 \\
6.611 \\
9.671 \\
11.361 \\
10.929 \\
8.314\end{array}$ \\
\hline LKA & $\begin{array}{c}1 \\
2 \\
3 \\
\text { Avg }\end{array}$ & $\begin{array}{r}0.077 \\
-0.027 \\
0.025\end{array}$ & $\begin{array}{r}0.061 \\
-0.124 \\
-0.031\end{array}$ & $\begin{array}{l}0.760 \\
0.793 \\
0.843 \\
1.199\end{array}$ & $\begin{array}{l}2.843 \\
2.764 \\
3.945 \\
3.184\end{array}$ & $\begin{array}{l}2.378 \\
2.201 \\
2.504 \\
2.361\end{array}$ \\
\hline
\end{tabular}




\begin{tabular}{|c|c|c|c|c|c|c|}
\hline Country & Period & $\begin{array}{c}\text { ZHK } \\
\text { (Barro) }\end{array}$ & $\begin{array}{c}\text { ZHK } \\
\text { (Nehru) }\end{array}$ & $\mathrm{K} / \mathrm{Y}$ & HKN/K & $\mathrm{HKB} / \mathrm{K}$ \\
\hline THA & $\begin{array}{c}1 \\
2 \\
3 \\
4 \\
5 \\
6 \\
\text { Avg }\end{array}$ & $\begin{array}{r}0.072 \\
0.087 \\
0.068 \\
0.174 \\
0.100\end{array}$ & $\begin{array}{l}0.073 \\
0.078 \\
0.051 \\
0.181 \\
0.045 \\
0.086\end{array}$ & $\begin{array}{l}0.905 \\
1.264 \\
1.631 \\
1.756 \\
1.931 \\
1.867 \\
1.559\end{array}$ & $\begin{array}{l}3.357 \\
5.201 \\
6.433 \\
7.192 \\
5.376 \\
4.507 \\
5.344\end{array}$ & $\begin{array}{r}3.060 \\
4.752 \\
5.685 \\
5.958 \\
4.437 \\
4.779\end{array}$ \\
\hline AUT & $\begin{array}{c}1 \\
2 \\
3 \\
4 \\
5 \\
6 \\
\text { Avg }\end{array}$ & $\begin{array}{r}0.073 \\
-0.049 \\
0.064 \\
0.065 \\
0.071 \\
0.045\end{array}$ & $\begin{array}{r}-0.007 \\
-0.049 \\
0.045 \\
0.053 \\
0.066 \\
0.067 \\
0.029\end{array}$ & $\begin{array}{l}1.312 \\
1.756 \\
1.991 \\
2.253 \\
2.436 \\
2.499 \\
2.041\end{array}$ & $\begin{array}{l}1.191 \\
2.444 \\
3.199 \\
3.643 \\
3.008 \\
2.682 \\
2.694\end{array}$ & $\begin{array}{r}1.853 \\
3.285 \\
4.040 \\
4.234 \\
3.425 \\
\\
3.367\end{array}$ \\
\hline BEL & $\begin{array}{c}1 \\
2 \\
3 \\
4 \\
5 \\
6 \\
\text { Avg }\end{array}$ & $\begin{array}{r}-0.029 \\
0.031 \\
0.129 \\
0.063 \\
0.013 \\
0.041\end{array}$ & $\begin{array}{r}-0.041 \\
0.039 \\
0.122 \\
0.069 \\
0.017 \\
-0.003 \\
0.034\end{array}$ & $\begin{array}{l}1.473 \\
1.696 \\
1.768 \\
1.926 \\
2.013 \\
1.957 \\
1.805\end{array}$ & $\begin{array}{l}3.126 \\
4.430 \\
3.633 \\
2.968 \\
2.656 \\
2.742 \\
3.259\end{array}$ & $\begin{array}{r}2.197 \\
3.102 \\
2.517 \\
2.109 \\
1.913 \\
2.367\end{array}$ \\
\hline DNK & $\begin{array}{c}1 \\
2 \\
3 \\
4 \\
5 \\
6 \\
\text { Avg }\end{array}$ & & $\begin{array}{l}0.074 \\
0.032 \\
0.070 \\
0.067 \\
0.070 \\
0.063\end{array}$ & $\begin{array}{l}1.195 \\
1.627 \\
1.981 \\
2.155 \\
2.106 \\
2.062 \\
1.854\end{array}$ & $\begin{array}{l}1.145 \\
1.486 \\
1.630 \\
1.530 \\
1.243 \\
1.033 \\
1.344\end{array}$ & \\
\hline FIN & $\begin{array}{c}1 \\
2 \\
3 \\
4 \\
5 \\
6 \\
\text { Avg }\end{array}$ & $\begin{array}{r}0.019 \\
0.048 \\
0.104 \\
0.025 \\
0.047 \\
0.049\end{array}$ & $\begin{array}{l}0.030 \\
0.073 \\
0.094 \\
0.039 \\
0.062 \\
0.046 \\
0.057\end{array}$ & $\begin{array}{l}1.894 \\
2.218 \\
2.327 \\
2.575 \\
2.514 \\
2.475 \\
2.334\end{array}$ & $\begin{array}{l}2.667 \\
3.021 \\
2.536 \\
2.349 \\
2.199 \\
2.032 \\
2.467\end{array}$ & $\begin{array}{r}1.920 \\
2.393 \\
2.024 \\
1.927 \\
1.950 \\
2.043\end{array}$ \\
\hline
\end{tabular}




\begin{tabular}{|c|c|c|c|c|c|c|}
\hline Country & Period & $\begin{array}{c}\text { ZHK } \\
\text { (Barro) }\end{array}$ & $\begin{array}{c}\text { ZHK } \\
\text { (Nehru) }\end{array}$ & $\mathrm{K} / \mathrm{Y}$ & $\mathrm{HKN} / \mathrm{K}$ & $\mathrm{HKB} / \mathrm{K}$ \\
\hline \multirow[t]{7}{*}{ FRA } & 1 & -0.020 & -0.049 & 1.201 & 3.651 & 4.814 \\
\hline & 2 & 0.089 & 0.084 & 1.515 & 5.253 & 6.401 \\
\hline & 3 & 0.135 & 0.120 & 1.772 & 4.793 & 5.497 \\
\hline & 4 & 0.073 & 0.055 & 1.967 & 5.140 & 5.508 \\
\hline & 5 & 0.056 & 0.048 & 2.096 & 3.682 & 3.747 \\
\hline & 6 & & 0.004 & 2.106 & 3.651 & \\
\hline & Avg & 0.067 & 0.044 & 1.776 & 4.362 & 5.193 \\
\hline \multirow[t]{6}{*}{ DEU } & 1 & & & 1.420 & 1.848 & 1.623 \\
\hline & 2 & 0.001 & -0.007 & 1.739 & 2.912 & 2.502 \\
\hline & 3 & -0.006 & -0.005 & 1.921 & 3.648 & 3.061 \\
\hline & 4 & 0.082 & 0.076 & 2.001 & 3.779 & 3.137 \\
\hline & 5 & 0.035 & 0.043 & 2.159 & 3.252 & 2.745 \\
\hline & Avg & 0.028 & 0.027 & 1.894 & 3.088 & 2.614 \\
\hline \multirow[t]{5}{*}{ GRC } & 2 & & & 1.729 & 6.060 & 7.344 \\
\hline & 3 & 0.028 & 0.022 & 2.027 & 8.322 & 9.931 \\
\hline & 4 & 0.123 & 0.103 & 2.152 & 7.681 & 8.578 \\
\hline & 5 & 0.074 & 0.072 & 2.334 & 7.280 & 7.768 \\
\hline & Avg & 0.075 & 0.066 & 1.984 & 7.336 & 8.405 \\
\hline \multirow[t]{6}{*}{ IRL } & 1 & & & 1.252 & 1.294 & 2.378 \\
\hline & 2 & 0.057 & 0.038 & 1.561 & 1.757 & 3.049 \\
\hline & 3 & 0.054 & 0.040 & 1.871 & 2.233 & 3.547 \\
\hline & 4 & 0.043 & 0.004 & 2.082 & 2.479 & 3.570 \\
\hline & 5 & 0.037 & 0.028 & 2.250 & 2.411 & 3.151 \\
\hline & Avg & 0.048 & 0.028 & 1.856 & 2.035 & 3.139 \\
\hline \multirow[t]{7}{*}{ ITA } & 1 & & & 1.676 & 2.660 & 2.770 \\
\hline & 2 & -0.032 & -0.043 & 1.885 & 4.272 & 4.312 \\
\hline & 3 & 0.040 & 0.045 & 2.083 & 5.628 & 5.598 \\
\hline & 4 & 0.078 & 0.081 & 2.093 & 4.821 & 4.851 \\
\hline & 5 & 0.056 & 0.054 & 2.165 & 4.642 & 4.680 \\
\hline & 6 & & 0.099 & 2.133 & 4.010 & \\
\hline & Avg & 0.035 & 0.047 & 2.006 & 4.339 & 4.442 \\
\hline \multirow[t]{6}{*}{ MLT } & 1 & 0.081 & . & 2.379 & & 6.493 \\
\hline & 2 & 0.158 & . & 2.873 & . & 5.810 \\
\hline & 3 & -0.019 & . & 2.759 & . & 6.124 \\
\hline & 4 & 0.107 & . & 1.870 & . & 4.797 \\
\hline & 5 & 0.027 & . & 2.023 & . & 5.040 \\
\hline & Avg & 0.071 & & 2.351 & . & 5.653 \\
\hline
\end{tabular}




\begin{tabular}{|c|c|c|c|c|c|c|}
\hline Country & Period & $\begin{array}{c}\text { ZHK } \\
\text { (Barro) }\end{array}$ & $\begin{array}{c}\text { ZHK } \\
\text { (Nehru) }\end{array}$ & $\mathrm{K} / \mathrm{Y}$ & HKN/K & $\mathrm{HKB} / \mathrm{K}$ \\
\hline NLD & $\begin{array}{c}1 \\
2 \\
3 \\
4 \\
5 \\
6 \\
\text { Avg }\end{array}$ & $\begin{array}{r}0.185 \\
0.050 \\
0.042 \\
0.035 \\
\\
0.078\end{array}$ & $\begin{array}{l}0.069 \\
0.064 \\
0.055 \\
0.050 \\
0.125 \\
0.073\end{array}$ & $\begin{array}{l}1.511 \\
1.830 \\
1.976 \\
2.070 \\
2.201 \\
2.195 \\
1.964\end{array}$ & $\begin{array}{l}3.423 \\
4.377 \\
4.303 \\
3.930 \\
3.604 \\
2.906 \\
3.757\end{array}$ & $\begin{array}{r}3.672 \\
3.299 \\
2.875 \\
2.771 \\
2.702 \\
3.064\end{array}$ \\
\hline NOR & $\begin{array}{c}1 \\
2 \\
3 \\
4 \\
5 \\
6 \\
\text { Avg }\end{array}$ & $\begin{array}{r}0.011 \\
0.109 \\
0.130 \\
0.118 \\
0.045 \\
\\
0.083\end{array}$ & $\begin{array}{r}-0.002 \\
0.100 \\
0.110 \\
0.082 \\
0.050 \\
0.168 \\
0.085\end{array}$ & $\begin{array}{l}1.686 \\
1.902 \\
2.073 \\
2.377 \\
2.923 \\
2.883 \\
2.307\end{array}$ & $\begin{array}{l}2.573 \\
2.681 \\
2.175 \\
1.912 \\
2.231 \\
1.934 \\
2.251\end{array}$ & $\begin{array}{r}3.079 \\
3.040 \\
2.331 \\
1.723 \\
1.973 \\
2.429\end{array}$ \\
\hline PRT & $\begin{array}{c}2 \\
3 \\
4 \\
5 \\
\text { Avg }\end{array}$ & $\begin{array}{r}-0.005 \\
0.364 \\
0.203 \\
0.044 \\
0.117\end{array}$ & $\begin{array}{l}0.163 \\
0.275 \\
0.087 \\
0.042 \\
0.111\end{array}$ & $\begin{array}{l}2.438 \\
2.659 \\
2.854 \\
3.160 \\
2.819\end{array}$ & $\begin{array}{r}22.356 \\
13.123 \\
8.910 \\
7.098 \\
12.872\end{array}$ & $\begin{array}{r}44.456 \\
26.805 \\
11.808 \\
8.198 \\
22.817\end{array}$ \\
\hline ESP & $\begin{array}{c}1 \\
2 \\
3 \\
4 \\
\text { Avg }\end{array}$ & $\begin{array}{l}0.118 \\
0.109 \\
0.112 \\
0.041 \\
0.095\end{array}$ & $\begin{array}{l}0.106 \\
0.070 \\
0.118 \\
0.097 \\
0.098\end{array}$ & $\begin{array}{l}1.201 \\
1.544 \\
1.790 \\
2.049 \\
1.817\end{array}$ & $\begin{array}{r}8.612 \\
10.564 \\
10.869 \\
8.269 \\
9.578\end{array}$ & $\begin{array}{l}11.294 \\
12.099 \\
11.924 \\
10.439 \\
11.439\end{array}$ \\
\hline SWE & $\begin{array}{c}1 \\
2 \\
3 \\
4 \\
5 \\
6 \\
\text { Avg }\end{array}$ & $\begin{array}{r}0.020 \\
0.099 \\
0.004 \\
0.090 \\
0.048 \\
0.052\end{array}$ & $\begin{array}{r}0.026 \\
0.106 \\
0.001 \\
0.091 \\
0.044 \\
-0.000 \\
0.045\end{array}$ & $\begin{array}{l}1.331 \\
1.638 \\
1.817 \\
1.978 \\
2.026 \\
2.041 \\
1.805\end{array}$ & $\begin{array}{l}1.221 \\
1.291 \\
1.493 \\
1.327 \\
1.114 \\
1.061 \\
1.251\end{array}$ & $\begin{array}{r}1.246 \\
1.366 \\
1.572 \\
1.403 \\
1.157 \\
1.349\end{array}$ \\
\hline $\mathrm{CHE}$ & $\begin{array}{c}1 \\
2 \\
3 \\
\text { Avg }\end{array}$ & $\begin{array}{r}-0.066 \\
0.072 \\
0.003\end{array}$ & $\begin{array}{r}-0.066 \\
0.050 \\
-0.008\end{array}$ & $\begin{array}{l}1.282 \\
1.620 \\
1.852 \\
1.911\end{array}$ & $\begin{array}{l}1.499 \\
2.774 \\
3.717 \\
2.663\end{array}$ & $\begin{array}{l}1.228 \\
2.263 \\
2.845 \\
2.112\end{array}$ \\
\hline TUR & $\begin{array}{c}4 \\
5 \\
6 \\
\text { Avg }\end{array}$ & $\begin{array}{r}-0.127 \\
-0.017 \\
-0.072\end{array}$ & $\begin{array}{r}-0.123 \\
-0.020 \\
0.049 \\
-0.032\end{array}$ & $\begin{array}{l}1.956 \\
2.167 \\
2.049 \\
1.739\end{array}$ & $\begin{array}{r}8.308 \\
11.352 \\
14.591 \\
11.417\end{array}$ & $\begin{array}{r}9.073 \\
12.065\end{array}$ \\
\hline
\end{tabular}




\begin{tabular}{||c|c|r|r|r|r|r||}
\hline Country & Period & $\begin{array}{c}\text { ZHK } \\
\text { (Barro) }\end{array}$ & $\begin{array}{c}\text { ZHK } \\
(\text { Nehru })\end{array}$ & K/Y & HKN/K & HKB/K \\
\hline \hline \multirow{2}{*}{ GBR } & 2 &. & & 1.443 & 2.019 & 2.009 \\
& 3 & 0.097 & 0.077 & 1.673 & 2.279 & 2.095 \\
& 4 & 0.019 & 0.021 & 1.805 & 2.082 & 1.891 \\
& 5 & 0.023 & 0.033 & 1.884 & 2.127 & 2.009 \\
& Avg & 0.046 & 0.044 & 1.623 & 2.127 & 2.001 \\
\hline \multirow{2}{*}{ NZL } & 1 & 0.073 & 0.077 & 1.193 & 5.598 & 3.139 \\
& 2 & 0.068 & 0.070 & 1.372 & 5.270 & 3.008 \\
& 3 & 0.127 & 0.128 & 1.530 & 4.262 & 2.426 \\
& 4 & 0.056 & 0.058 & 1.807 & 3.840 & 2.222 \\
& 5 & 0.005 & 0.029 & 1.808 & 3.113 & 1.968 \\
& 6 & & 0.215 & 2.000 & 2.566 &. \\
& Avg & .066 & 0.096 & 1.618 & 4.108 & 2.553 \\
\hline
\end{tabular}




\section{References}

Alderman, Harold, et al., "Public Schooling Expenditures in Rural Pakistan: Efficiently Targeting Girls and a Lagging Region," in Kim Nead and Dominique van de Walle, eds., Public Expenditures and the Poor: Incidence and Targetting. Washington, DC: The World Bank, 1994.

Alderman, Harold, et al., "The Gender Gap in Cognitive Skills in a Poor Rural Economy," mimeo, December 1991.

Azariadis, Costas, and Allan Drazen, "Threshold Externalities in Economic Development," Quarterly Journal of Economics 105:2 (May 1990), pp. 501-526.

Barro, Robert, and Jong-Wha Lee, "International Comparisons of Educational Attainment, 1960-1985," Mimeo, Harvard University, June 1992.

Barro, Robert J., and Xavier Sala-i-Martin, "Two-Sector Models of Endogenous Growth (with special attention to the role of human capital), Chapter 4 in Economic Growth, by Barro and Sala-i-Martin (Forthcoming).

Behrman, Jere R., and Nancy Birdsall, "The Quality of Schooling: Quantity Alone is Misleading," American Economic Review 73:5 (1983), pp. 928-946.

Benhabib, Jess, and Mark Spiegel, "Growth Accounting with Physical and Human Capital Accumulation," Economic Research Report \#91-66, C.V. Starr Center for Applied Economics, New York University, 1991.

Bickel, Peter J., and Kjell A. Doksum. Mathematical Statistics: Basic Ideas and Selected Topics. Oakland, California: Holden-Day, Inc., 1977.

Birdsall, Nancy, and J. Behrman, "Does Geographical Aggregation Cause Overestimates of the Returns to Schooling?" Oxford Bulletin of Economics and Statistics 46 (1984).

Cohen, Daniel, "Economic Growth and the Solow Model: Some Further Empirical Results," Mimeo, CEPREMAP, February 1993.

Cohen, Daniel, "A Note on the Idiosyncratic Determinants of Economic Growth," Mimeo, CEPREMAP, February 1993.

Dougherty, Christopher, and George Psacharopoulos, "Measuring the Cost of Misallocation of Investment in Education," Journal of Human Resources 12:4 (1977), 446-459.

Fallon, P. R. and P.R.G. Layard, "Capital-Skill Complementarity, Income Distribution, and Output Accounting," Journal of Political Economy 83:2 (1975), pp. 279-301.

Galor, Oded, and Joseph Zeira, "Income Distribution and Macroeconomics," Brown University Working Paper No. 89-25, July 1988. 
Greene, William H. Econometric Analysis. New York: Macmillan, 1992.

Griliches, Zvi, "Estimating the returns to schooling: Some econometric problems," Econometrica 45 (1977), pp. $1-22$.

Griliches, Zvi, "Sibling Models and Data in Economics: Beginnings of a Survey," Journal of Political Economy 87:S (1979), pp. 37-64.

Griliches, Zvi, and W. Mason, "Education, Income, and Ability," Journal of Political Economy 80 (1972), pp. S74-S103.

Hause, John C., "Earnings Profile: Ability and Schooling," Journal of Political Economy 80:3 (1972 Supplement), pp. 108-138.

Hausman, Jerry A., "Specification Tests in Econometrics," Econometrica 46 (1978), pp. 1251-1272.

Hausman, Jerry A., and William B. Taylor, "Panel Data and Unobservable Individual Effects," Econometrica 49:6 (November 1981), pp. 1377-1398.

Hopkins, Kenneth D., et al. Educational and Psychological Measurement and Evaluation. Englewood Cliffs, New Jersey: Prentice-Hall, Inc., 1990.

Jovanovic, Boyan, Saul Lach, and Victor Lavy, "Growth and Human Capital as Cost-Reducing Investment," Paper presented at the conference "Growth and Income Distribution," Paris, December 1992.

Kendrick, John W. The Formation and Stocks of Total Capital. New York: Columbia University Press for the National Bureau of Economic Research, 1976.

Knight, John B., and Richard Sabot. Education, Productivity, and Inequality: The East African Natural Experiment. New York: Oxford University Press, 1990.

Lau, Lawrence, Dean Jamison, and Frederic Louat, "Education and Productivity in Developing Countries: An Aggregate Production Function Approach," World Bank PRE Working Paper Series No. 612 (1991).

Levine, Ross, and David Renelt, "A Sensitivity Analysis of Cross-Country Growth Regressions," mimeo, World Bank, December 1990.

Lucas, Robert E., "On the Mechanics of Economic Development," Journal of Monetary Economics 22 (1988), pp. 3-42.

Mankiw, N. Gregory, David Romer, and David N. Weil, "A Contribution to the Empirics of Economic Growth," Quarterly Journal of Economics 107:2 (May 1992), pp. 407-438.

Marshall, Alfred. Principles of Economics. London: Macmillan, 1930.

Mincer, Jacob. Schooling, Experience, and Earnings. New York: Columbia University Press, 1974. 
Mingat, Alain, and J.P. Tan, "On Equity in Education Again: An International Comparison," Journal of Human Resources (Spring 1985), pp. 298-308.

Nehru, Vikram, Eric Swanson, and Ashutosh Dubey, "A New Database on Human Capital Stock: Sources, Methodology and Results," World Bank Policy Research Working Paper 1124 (April 1993).

Newey, Whitney K., and Kenneth D. West, "A Simple, Positive Semi-Definite, Heteroscedasticity and Autocorrelation Consistent Covariance Matrix," Econometrica 55 (1987), pp. 703-708.

Piñera, S., and M. Selowsky, "The Optimal Ability-Education Mix and the Misallocation of Resources Within Education," Journal of Development Economics 8 (1981), pp. 111-131.

Psacharopoulos, George, "Returns to Education: A Further International Update and Implications," Journal of Human Resources 20:4 (1985), pp. 583-604.

Psacharopoulos, George. Financing Education in Developing Countries: An Exploration of Policy Options. Washington, DC: World Bank, 1986.

Psacharopoulos, George, "Returns to Investment in Education: A Global Update," World Bank Policy Reseach Working Paper 1057, January 1993.

Psacharopoulos, George, et al., "Manpower Issues in Educational Investment: A Consideration of Planning Processes and Techniques," World Bank Working Paper WBSWP \#624.

Psacharopoulos, George, and Ana-Maria Arriagada, "The International Composition of the Labor Force: An International Comparison," International Labour Review 125:5 (September-October 1986), pp. 561-574.

Psacharopoulos, George, and Ying Chu Ng, "Earnings and Education in Latin America: Assessing Priorities for Schooling Investments," World Bank Policy Reseach Working Paper 1056, December 1992.

Psacharopoulos, George, and Richard Layard, "Human Capital and Earnings: British Evidence and a Critique," The Review of Economic Studies 56:3 (July 1979), pp. 485-503.

Psacharopoulos, George, and Eduardo Velez, "Schooling, Ability, and Earnings in Colombia, 1988," Economic Development and Cultural Change (1992), pp. 629-643.

Psacharopoulos, George, and Maureen Woodhall. Education for Development: An Analysis of Investment Choices. New York: Oxford University Press for The World Bank, 1985.

Romer, Paul M., "Human Capital and Growth: Theory and Evidence," Carnegie-Rochester Conference Series on Public Policy 32 (1990), pp. 251-286.

Schmidt, Stefanie, "Do School Inputs Matter? Historical Evidence from New York State," Mimeo, MIT, 1993.

Solow, Robert M., "Technical Change and the Aggregate Production Function," Review of Economics and Statistics 39 (1957), pp. 312-320. 
Spence, Michael, "Job Market Signaling," Quarterly Journal of Economics 87 (1973), pp. 355-374.

Winkler, Donald R., "Higher Education in Latin America: Issues of Efficiency and Equity," World Bank Working Paper WBDP 77, 1990.

Wolfle, Dael. The Uses of Talent. Princeton, New Jersey: Princeton University Press, 1971.

World Development Report 1991. New York: Oxford University Press for The World Bank, 1991.

World Development Report 1993. New York: Oxford University Press for The World Bank, 1993. 